\title{
A wind tunnel study of the effect of downstream buildings on near-field pollutant
} dispersion

\section{B. Hajra*, T. Stathopoulos}

Department of Building, Civil and Environmental Engineering, Concordia University, Montreal, Canada

\begin{abstract}
The effect of near-field pollutant dispersion characteristics for the case of downstream buildings in the urban environment has been presented in this paper. Wind tunnel data were obtained for nine different building configurations, three exhaust momentum ratios $(\mathrm{M})$ and three stack heights $\left(\mathrm{h}_{\mathrm{s}}\right)$, for wind azimuth of $0^{\circ}$. Tracer gas concentrations were measured on the roof, windward and leeward walls of each building. When a tall downstream building was located within the recirculation length of the emitting building, higher rooftop concentration was measured on the emitting building than for the isolated building case. Results also show that the height and across-wind dimension of the downstream building, as well as the spacing between buildings are critical parameters in assessing plume dilution. ASHRAE 2007 and ASHRAE 2011, which apply Gaussian-based models for the evaluation of dilution, are unable to model the effect of adjacent buildings; the former yielded lower dilution for all cases examined whilst the latter was found to be suitable only for specific limited cases. Design guidelines for the placement of stack and intakes to avoid or minimize plume re-ingestion are proposed.
\end{abstract}

Keywords: ASHRAE 2007; ASHRAE 2011; Dilution; Downstream building; Near-field; Wind tunnel

*Corresponding author.Tel.001-514-848-2424; ext: 3211

E-mail address: b_hajra@encs.concordia.ca 


\section{Introduction}

Dispersion of pollutants in the urban environment has been the subject of study for several decades due to potential health hazards associated with them [1]. Pollutants released from rooftop stacks within the recirculation length of a building can affect indoor air quality by entering the emitting building or an adjacent building in the nearvicinity [2].

Far-field pollutant dispersion has been the subject of study by various researchers. For instance, Kesarkar et al. [3] studied the pollutant flow through the city of Pune in India and compared field data with AERMOD. The flow-structure of the plume in nearfield dispersion is greatly influenced by adjacent buildings, in addition to atmospheric turbulence [4].

It is difficult to distinguish clearly between near-field and far-field dispersion problems. For instance, Li and Meroney. [5] defined the "near-wake" region as $\mathrm{x} / \mathrm{H}<5$, where $\mathrm{x}$ is the distance of the receptor from the source and $\mathrm{H}$ is the height of the building. Similarly based on water channel experiments, Wilson et al. [6] defined near-field to be within the "recirculation region" from the source which can be estimated from the upwind dimensions of the building, the results of this study are still being used in ASHRAE 2011 [7].

Plumes released from isolated buildings have been studied by various researchers, e.g. Wilson. [8]; Schulman and Scire. [9] and others. Since buildings in the urban environment are seldom found in isolation, pollutant dispersion studies pertaining to the effect of neighbouring buildings is more realistic. A recent study involving the effects of upstream buildings on near-field pollutant dispersion showed that the recirculation length of the upstream building and spacing between them were critical parameters in altering the plume geometry when pollutants are emitted from the roof of the downstream building [10]. Experimental data for a few upstream building configurations were also used to assess the performance of CFD using Realisable k- $\varepsilon$ model for different Turbulent Schmidt numbers $\left(\mathrm{Sc}_{\mathrm{t}}\right)$; the agreement between experiment and numerical modelling was largely dependent on $\mathrm{Sc}_{t}$ [11]. Pollutant flow from rooftop emissions is known to be different in the presence of downstream buildings, as shown through limited studies by Wilson et al. [6] and Petersen et al. [12]. Pollutant re-ingestion can occur in the presence 
of upstream or downstream buildings. Since the former has been the subject of extensive studies, the latter requires further investigation. Therefore, the present study extends the ongoing research to assess the effect of buildings of different geometries placed downstream of an emitting building.

Most available dispersion models such as ADMS and SCREEN are capable of assessing plume dilution only on ground level receptors and also assume a uniform concentration distribution within the recirculation length [10]. However, ASHRAE 2007 and ASHRAE 2011 are capable of assessing dilution on rooftop receptors.

This paper examines wind tunnel results for nine different configurations, three different stack heights $\left(\mathrm{h}_{\mathrm{s}}\right)$ of 1, 3 and $5 \mathrm{~m}$ and exhaust momentum ratios $(\mathrm{M})$ of 1,2 and 3 at wind angle of $0^{\circ}$. Although, experiments were also performed at wind azimuth of 45 degrees, $0^{\circ}$ was found to be most critical. The configurations consist of buildings of various geometries placed downwind of an emitting building. The experiments were performed in the open circuit Boundary Layer Wind Tunnel Laboratory of Concordia University. The building models used in the present study have a flat roof, with receptors located on the roof, leeward and windward walls. Results were compared to those generated by ASHRAE 2007 and ASHRAE 2011 models.

Section 2 of this paper describes the pollutant transport within the recirculation zone of a building, followed by a description of ASHRAE 2007 and 2011 versions in sections 3 and 4 respectively. The experimental procedure and the configurations examined have been discussed in section 5. Results and discussion are presented in section 6 followed by a summary of results and conclusions in sections 7 and 8 respectively.

\section{Transport of airborne pollutants within recirculation areas}

The transport of airborne particles within the recirculation zone in the wake of an isolated building is shown in Figure 1. According to Wilson. [8], the size of the recirculation region (shown as $L_{r}$ in Figure 1) is estimated by using the building dimensions perpendicular to wind direction:

$$
L_{r}=B_{s}^{0.67} B_{L}^{0.33}
$$

where:

$L_{r}$ is the zone of recirculating flow $(\mathrm{m})$, 
$B_{s}$ is the smaller building dimension perpendicular to wind direction (m), $B_{L}$ is the larger building dimension perpendicular to wind direction (m).

Owing to the upwind dimensions of the building, turbulence is generated which extends up to about 1.5 times ' $R$ ' from the roof of the building, where ' $R$ ' is the scaling length for roof flow patterns. The value of ' $R$ ' is obtained from equation 1 , by replacing ' $L_{r}$ ' by ' $\mathrm{R}$ '. Pollutants released from rooftop stack form a triangle (in two dimensions) with the edges at 5:1 away from the plume centreline. Furthermore, when the along wind dimension ' $L$ ' is relatively long then the flow re-attaches resulting in an additional recirculation length $\left(L_{c}\right)$ on the roof besides $L_{r}$ in the wake, as shown in Figure 1. However, Wilson et al. [6] was able to show that the plume trajectory from a rooftop stack in the presence of a downstream building is markedly different from an isolated case, as shown in Figure 2. The study showed that although a taller downstream building prevented the plume from dispersing along the roof of the emitting building a small portion of the plume also escaped from the sides as "side-leakage". The study also showed that there was increased plume spread beyond the roof edge recirculation cavity of the downstream building causing more pollutant deposition due to "upwash". However, previous studies did not focus on a detailed analysis by considering change in various parameters such as the building dimensions, spacing between buildings, change in stack height and location and exhaust speeds.

\section{ASHRAE 2007}

ASHRAE Applications Handbook, Chapter 44, 2007, has two methods for the evaluation of pollutant dispersion around an emitting building, namely: Geometric design method and the Gaussian plume equations [13]. The former is a qualitative approach used for assessing minimum stack height to avoid recirculation region whilst the latter is a quantitative technique used to estimate plume dilution at a given rooftop receptor. In the present study, the latter is discussed in greater detail.

The Gaussian plume equations are based on the dimensions of flow recirculation zones that form on the building:

$$
\begin{aligned}
H_{c} & =0.22 L_{r} \\
X_{c} & =0.5 L_{r}
\end{aligned}
$$


$L_{c}=0.9 L_{r}$

where: $\mathrm{H}_{\mathrm{c}}$ is the maximum height of the roof recirculation zone $(\mathrm{m})$,

$\mathrm{X}_{\mathrm{c}}$ is the distance from the leading edge to $\mathrm{H}_{\mathrm{c}}(\mathrm{m})$,

$\mathrm{L}_{\mathrm{c}}$ is the length of the roof recirculation zone $(\mathrm{m})$

The design method assumes that the boundary of the high turbulence region is defined by a line with a slope of 10:1 extending from the top of the leading edge separation bubble - see Figure 1. ASHRAE 2007 also estimates plume dilution as the ratio of exhaust $\left(\mathrm{C}_{\mathrm{e}}\right)$ to receptor concentration $\left(\mathrm{C}_{\mathrm{r}}\right)$ so that irrespective of the chemical properties of the pollutant, the concentrations can be reduced to non-dimensional ratios for ease of comparison. The parameters required for assessing dilution include the effective height of the plume (h) above the roof:

$h=h_{s}+h_{r}-h_{d}$

where:

$\mathrm{h}_{\mathrm{s}}$ is stack height $(\mathrm{m})$,

$\mathrm{h}_{\mathrm{r}}$ is plume rise $(\mathrm{m})$ and

$h_{d}$ is the reduction in plume height due to entrainment into the stack wake during periods of strong winds $(\mathrm{m})$.

Exhaust momentum ratio $(\mathrm{M})$ is defined as:

$M=\left(\rho_{e} / \rho_{a}\right)^{0.5}\left(V_{e} / U_{H}\right)$

where

$\rho_{\mathrm{e}}$ and $\rho_{\mathrm{a}}$ are the densities of exhaust and air respectively $\left(\mathrm{kg} / \mathrm{m}^{3}\right)$,

$\mathrm{V}_{\mathrm{e}}$ is the exhaust velocity $(\mathrm{m} / \mathrm{s})$,

$\mathrm{U}_{\mathrm{H}}$ is the wind velocity at building height $(\mathrm{m} / \mathrm{s})$

Equation 6 reduces to a ratio of velocities since the densities of exhaust and air are nearly equal for non-buoyant tracer studies in the wind tunnel [2], i.e.

$\mathrm{M}=\mathrm{V}_{\mathrm{e}} / \mathrm{U}_{\mathrm{H}}$

Plume rise, which is assumed to occur instantaneously, is calculated using the formula of Briggs. [14]:

$h_{r}=3 \beta d_{e}\left(V_{e} / U_{H}\right)$

where: $d_{e}$ is the stack diameter $(m)$, 
$\mathrm{V}_{\mathrm{e}}$ is the exhaust velocity $(\mathrm{m} / \mathrm{s})$,

$\mathrm{U}_{\mathrm{H}}$ is the wind speed at building height $(\mathrm{m} / \mathrm{s})$

and $\beta$ is the stack capping factor. The value of $\beta$ is 1 for uncapped stacks and 0 for capped stacks.

To account for the stack downwash caused by low exit velocities, when $\mathrm{V}_{\mathrm{e}} / \mathrm{U}_{\mathrm{H}}<3.0$,

Wilson et al. [6] recommended a stack wake downwash adjustment $h_{d}$, which is defined as:

$h_{d}=d_{e}\left(3-\beta V_{e} / U_{H}\right)$

For $\mathrm{V}_{\mathrm{e}} / \mathrm{U}_{\mathrm{H}}>3.0$ there is no stack downwash $\left(\mathrm{h}_{\mathrm{d}}=0\right)$.

Dilution at roof level in a Gaussian plume emitted at the final rise plume height of $\mathrm{h}$ is:

$D_{r}=4\left(U_{H} / V_{e}\right)\left(\sigma_{y} / d_{e}\right)\left(\sigma_{z} / d_{e}\right) \exp \left(\zeta^{2} / 2 \sigma_{z}{ }^{2}\right)$

where: $\zeta=\mathrm{h}-\mathrm{H}_{\mathrm{c}}$

$$
=0 \text { if } \mathrm{h}<\mathrm{H}_{\mathrm{c}}
$$

$\zeta$ is the vertical separation between ' $h$ ' and $\mathrm{H}_{\mathrm{c}}$, the latter is defined in Figure 1.

Essentially, equation 10 is the inverse of a standard Gaussian plume expression to estimate rooftop concentrations, with the total emission rate (Q) expressed in terms of exhaust diameter $\left(\mathrm{d}_{\mathrm{e}}\right)$ and exhaust speed $\left(\mathrm{V}_{\mathrm{e}}\right)$.

The plume equations are as follows:

$\sigma_{y} / d_{e}=0.071\left(t_{\text {avg }} / 2\right)^{0.2}\left(X / d_{e}\right)+\sigma_{o} / d_{e}$

$\sigma_{z} / d_{e}=0.071\left(X / d_{e}\right)+\sigma_{o} / d_{e}$

The dependence of initial spread $\sigma_{o}$ on exit velocity to wind speed ratio $V_{e} / U_{H}$ is

$\sigma_{o} / d_{e}=\left[0.125 \beta\left(V_{e} / U_{H}\right)+0.911 \beta\left(V_{e} / U_{H}\right)^{2}+0.25\right]^{0.5}$

where:

$t_{\text {avg }}$ is the concentration averaging time in minutes,

$\mathrm{X}$ is the distance downwind from the stack (m),

$\sigma_{\mathrm{y}}$ and $\sigma_{\mathrm{z}}$ are standard deviations of the plume $(\mathrm{m})$.

$\sigma_{o}$ is the initial source size that accounts for stack diameter and for dilution jet entrainment during plume rise (m). The following section describes the ASHRAE 2011 model, which was published recently. 


\section{ASHRAE 2011}

ASHRAE 2011 has undergone significant changes compared to the 2007 version discussed previously. New formulations for estimating plume rise $\left(h_{r}\right)$, plume spread parameters $\left(\sigma_{y}\right.$ and $\left.\sigma_{z}\right)$ and dilution for shorter time periods have been suggested. Plume rise $\left(h_{r}\right)$ is estimated as

$h_{r}=\min \left\{\beta h_{x}, \beta h_{f}\right\}$

where

$\beta$ is the stack capping factor - see equation 8 ,

$h_{x}$ and $h_{f}$ are estimated as

$h_{x}=\frac{3 V_{e}^{2} d_{e}^{2} X}{4 \beta_{j}{ }^{2} U_{H}{ }^{2}}$

$h_{f}=\frac{0.9\left[\left(V_{e}^{2} d_{e}^{2} / 4\right)\left(U_{H} / U_{*}\right)\right]^{0.5}}{\beta_{j} U_{H}}$

where

$U *$ is the friction velocity $(\mathrm{m} / \mathrm{s})$,

$\beta_{j}$ is the jet entrainment coefficient calculated by

$\beta_{j}=\frac{1}{3}+\frac{U_{H}}{V_{e}}$

The logarithmic wind profile equation is

$U_{H} / U_{*}=2.5 \ln \left(H / Z_{o}\right)$

where

$Z_{o}$ is the surface roughness length (m)

It may be noted that the plume rise as per ASHRAE 2007 (equation 8) were functions of the exhaust velocity ratio $\left(\mathrm{V}_{\mathrm{e}} / \mathrm{U}_{\mathrm{H}}\right)$ and stack diameter $\left(\mathrm{d}_{\mathrm{e}}\right)$ whilst the 2011 version also incorporates the effects of wind profile and stack-receptor distance (X).

The plume spread parameters $\left(\sigma_{\mathrm{y}}\right.$ and $\left.\sigma_{\mathrm{z}}\right)$ are calculated using the formulations of Cimoreli et al. [15]

$$
\begin{aligned}
& \sigma_{y}=\left(i_{y}{ }^{2} X^{2}+\sigma_{0}{ }^{2}\right)^{0.5} \\
& \sigma_{z}=\left(i_{z}{ }^{2} X^{2}+\sigma_{0}{ }^{2}\right)^{0.5}
\end{aligned}
$$


where

$i_{x}, i_{y}$ and $i_{z}$ are the turbulence intensities in $\mathrm{x}, \mathrm{y}$ and $\mathrm{z}$ directions,

$i_{x}=\left[0.24+0.096 \log _{10}\left(Z_{o}\right)+0.016\left(\log _{10} Z_{o}\right)^{2}\right]\left[\ln \left(30 / Z_{o}\right) / \ln \left(Z / Z_{o}\right)\right]$

$i_{y}=0.75 i_{x}$

$i_{z}=0.5 i_{x}$

$\sigma_{\mathrm{o}}$ is the initial source size and is set equal to $0.35 \mathrm{~d}_{\mathrm{e}}(\mathrm{m})$,

$Z$ is the height of the plume above the rooftop (m)

As discussed previously, ASHRAE 2007 estimated the source size $\left(\sigma_{0}\right)$ based on M and $d_{e}$ whilst ASHRAE 2011 calculates it as a function of $d_{e}$. The dilution is calculated using equation 10 which according to ASHRAE 2011 is equivalent to 10-15 minutes field averaging time. For shorter averaging times dilution estimates are obtained by:

$$
\left(D_{r}\right)_{s}=D_{r}\left(t_{s} / 15\right)^{0.2}
$$

where

$\left(D_{r}\right)_{s}$ is the dilution estimated for a shorter averaging time $\mathrm{t}_{\mathrm{s}}$,

$\mathrm{t}_{\mathrm{s}}$ is the averaging time in minutes,

$D_{r}$ is the dilution calculated as per equation 10 .

The introduction of averaging time is a significant contribution of ASHRAE 2011 since this was not part of previous versions of ASHRAE. Averaging time greatly influences the dispersion process especially at the micro-scale level.

It is worth noting that although $\mathrm{D}_{\mathrm{r}}$ is expressed as $\mathrm{C}_{\mathrm{e}} / \mathrm{C}_{\mathrm{r}}$ in ASHRAE, the receptor concentration $\left(\mathrm{C}_{\mathrm{r}}\right)$ is proportional to the pollutant emission rate $\mathrm{Q}$ and not exhaust concentration $\left(\mathrm{C}_{\mathrm{e}}\right)$ since the latter may be altered by addition of air without affecting receptor concentrations. Dilution calculated from equations 10 and 24 along with wind tunnel results have been converted to normalised dilution using the formulations of Wilson. [8] for comparison with previous studies.

$\mathrm{D}_{\text {normalised }}=\left(\mathrm{D}_{\mathrm{r}} \mathrm{Q}\right) /\left(\mathrm{U}_{\mathrm{H}} \mathrm{H}^{2}\right)$

where:

$\mathrm{Q}=\pi \mathrm{d}_{\mathrm{e}}^{2} \mathrm{~V}_{\mathrm{e}} / 4$ is the volumetric flow-rate $\left(\mathrm{m}^{3} / \mathrm{s}\right)$

$\mathrm{H}$ is the height of the building (m) 


\section{Experimental set-up}

Tracer experiments were performed at the Boundary Layer Wind Tunnel of Concordia University, which is $12.2 \mathrm{~m}$ long and has a $3.2 \mathrm{~m}^{2}$ cross-section. In order to simulate a thick atmospheric boundary layer, spires and coarse roughness elements are used. The wind tunnel floor panels had $5 \mathrm{~cm}$ cubes that were arranged staggered and spaced about $6 \mathrm{~cm}$ from each other. A power law exponent $(\alpha)$ of 0.31 , which corresponds to an urban terrain according to ASHRAE 2009 [16], was used for the study. The velocity and turbulence intensity profiles shown in Figure 3, were measured using a Cobra probe manufactured by Turbulent Flow Instrumentation. According to the instrument features, the accuracy of measurements is generally within $\pm 0.5 \mathrm{~m} / \mathrm{s}$ up to turbulence intensity values of about $30 \%$ [17]. The agreement between velocity profile obtained from the present study and ESDU [18] was found to be good close to the ground and at about $70 \mathrm{~cm}$ from the base. Although the turbulence intensity profiles showed similar characteristics, the values obtained by wind tunnel were somewhat less than those predicted by ESDU. [18]. This discrepancy is attributed to the formulations of ESDU which according to Liu et al. [19] were developed "by correlating strong wind atmospheric data over a large variety of different roughness conditions". Similar findings were observed by Liu et al. [19] whilst comparing turbulence profiles between wind tunnel and ESDU [18] for different terrain exposures.

A turbulent flow with stable time-averaged flow conditions was maintained throughout the tests. The roof of the tunnel was adjusted to ensure that the longitudinal static pressure gradient was negligible.

\subsection{Building configurations examined - field dimensions}

Nine different configurations were tested using six building models to assess nearfield plume characteristics of downstream buildings. The dimensions of each building model are presented in Table 1. The recirculation length was calculated by the ASHRAE method (Equation 1) and by the ADMS model methodology. 
Table 1 Full-scale dimensions of buildings considered

\begin{tabular}{|l|l|l|l|l|l|}
\hline Building & Height $(\mathrm{m})$ & Width $(\mathrm{m})$ & \multirow{2}{*}{ Breadth $(\mathrm{m})$} & \multicolumn{2}{|l|}{ Recirculation length (m) } \\
\cline { 4 - 6 } & & & & & \\
& & & & & \\
\hline $\mathrm{B}_{1}$ & 15 & 50 & 50 & 22.3 & 35.9 \\
\hline $\mathrm{B}_{2}$ & 30 & 50 & 30 & 35.5 & 50.0 \\
\hline $\mathrm{B}_{3}$ & 30 & 50 & 15 & 35.5 & 79.1 \\
\hline $\mathrm{B}_{4}$ & 30 & 30 & 30 & 30.0 & 43.5 \\
\hline $\mathrm{B}_{5}$ & 54 & 50 & 15 & 51.2 & 105.6 \\
\hline $\mathrm{B}_{6}$ & 30 & 50 & 50 & 35.5 & 55.1 \\
\hline
\end{tabular}

NB: Width refers to the dimension perpendicular to wind direction

The predictions of ADMS are based on Fackrell and Pearce [20]:

$$
L_{r}=\frac{1.8 W}{\left[(L / H)^{0.3}(1+0.24 W / H)\right]}
$$

$$
(0.3 \leq L / H \leq 3.0)
$$

When the ratio of $L / H$ lies outside the indicated range, $L_{r}$ is computed using the nearest limit. Table 1 shows that ADMS predicts higher values of $L_{r}$ than ASHRAE. In Equation $10, \zeta$ is defined as the difference between $h$ and $H_{c}$, which is the maximum height of the roof recirculation zone and is calculated from Equation 2 as a function of $\mathrm{R}$ $\left(\mathrm{L}_{\mathrm{r}}=\mathrm{R}\right)$. If ASHRAE predictions of $\mathrm{L}_{\mathrm{r}}$ were comparable to ADMS, the resulting values of $\zeta$ would predict lower dilution (higher rooftop concentrations) making the results even more conservative.

Buildings $\mathrm{B}_{1}$ and $\mathrm{B}_{6}$ were used as emitting buildings (buildings with rooftop stack) for the study. Figure 4 shows all building configurations considered and the receptor locations. The different configurations tested in the wind tunnel are also summarised in Table 2. When the downstream configurations/isolated cases were tested separately in the wind tunnel, no additional building was placed in the vicinity. The idea here is that these are the dominant buildings interacting with the flow, whereas the rest of the buildings are low and their influence is covered by the additional roughness in the flow. 
Table 2 Configurations tested in the wind tunnel

\begin{tabular}{|c|c|}
\hline No. & Configurations tested in the wind tunnel \\
\hline 1 & $\mathrm{~B}_{1}$ (isolated) \\
\hline 2 & $\mathrm{~B}_{2}$ downstream of $\mathrm{B}_{1}$ \\
\hline 3 & $\mathrm{~B}_{3}$ downstream of $\mathrm{B}_{1}$ \\
\hline 4 & $\mathrm{~B}_{4}$ downstream of $\mathrm{B}_{1}$ \\
\hline 5 & $\mathrm{~B}_{5}$ downstream of $\mathrm{B}_{1}$ \\
\hline $1 \mathrm{a}$ & $\mathrm{B}_{6}$ (isolated) \\
\hline $2 \mathrm{a}$ & $\mathrm{B}_{2}$ downstream of $\mathrm{B}_{6}$ \\
\hline $3 \mathrm{a}$ & $\mathrm{B}_{3}$ downstream of $\mathrm{B}_{6}$ \\
\hline $4 \mathrm{a}$ & $\mathrm{B}_{4}$ downstream of $\mathrm{B}_{6}$ \\
\hline
\end{tabular}

The spacing (S) between the buildings was varied from $10 \mathrm{~m}$ to $50 \mathrm{~m}$, because the aim of this study was to assess dilution within the building recirculation length. The lowest and highest value of the recirculation length of the building is $22.3 \mathrm{~m}$ and $51.2 \mathrm{~m}$ respectively, as shown in Table 1. The stack location from the upwind edge of the emitting building (X) was varied from 0 to $20 \mathrm{~m}$.

\subsection{Scaling considerations}

The building models were constructed of wood at a scale of 1:200. On the basis of the log-law velocity profile, the friction velocity $\left(U_{*}\right)$ is approximately equal to $1 \mathrm{~m} / \mathrm{s}$ and the model roughness length of the upstream exposure $\left(Z_{0}\right)$ is $3.5 \mathrm{~mm}$, which corresponds to a full-scale roughness length of $0.7 \mathrm{~m}$. The gradient height was found to be $95 \mathrm{~cm}$ in the wind tunnel (190 $\mathrm{m}$ full scale). This is due to the fact that the real geometric scale in the wind tunnel is between 1:400 and 1:500 [21] but previous studies by Saathoff et al. [22] demonstrate that a scale distortion up to a factor of 2 or so generates negligible errors to the results.

The turbulence length scale was estimated using the expression provided by Counihan. [23]:

$\mathrm{L}_{\mathrm{u}}^{\mathrm{x}}=\mathrm{Cz}^{\mathrm{m}}$

where the values of $\mathrm{C}$ and $\mathrm{m}$ are estimated from a graph at a particular value of height above the ground $(\mathrm{z})$ for a given $\mathrm{Z}_{\mathrm{o}} . \mathrm{L}_{\mathrm{u}}{ }^{\mathrm{x}}$ was estimated at the height of the low emitting building $(15 \mathrm{~m})$ in the present study and was found equal to $80 \mathrm{~m}$ corresponding to $0.4 \mathrm{~m}$ 
in the wind tunnel. However, for comparison purposes, the length scale was also evaluated according to ESDU [24]:

$\mathrm{L}_{\mathrm{u}}{ }^{\mathrm{x}}=25 \mathrm{z}^{0.35} \mathrm{Z}_{\mathrm{o}}{ }^{-0.063}$

Equation 28 yields $\mathrm{L}_{\mathrm{u}}{ }^{\mathrm{x}} \approx 66 \mathrm{~m}$ (full-scale), which is approximately $0.3 \mathrm{~m}$ at the wind tunnel scale.

The wind speed at building height $\left(\mathrm{U}_{\mathrm{H}}\right)$ was measured to be $6.2 \mathrm{~m} / \mathrm{s}$ in the wind tunnel. According to Snyder. [25] the following criteria need to be satisfied for modelling non-buoyant plume exhaust:

- Geometric similarity

- Building Reynolds Number $>11000$

- Stack Reynolds Number $>2000$

- Similarity of wind tunnel flow with atmospheric surface layer

- Equivalent stack momentum ratio.

The building and stack Reynolds number were evaluated to be 20000 and 1800 respectively. Although it has been suggested to place a trip around the stack to produce additional turbulence in order to achieve the stack Reynolds number criteria, Saathoff et al. [22] found that it is generally not possible to achieve this criteria for small diameter stacks since a trip cannot be placed around it. Although, the stack Reynolds number is somewhat less than 2000 , this does not seem to affect the measurements, as reported in previous wind tunnel studies under similar conditions by Saathoff et al. [22] and Stathopoulos et al. [26].

The effects of averaging time diminish when the stack and receptor are in close proximity to each other. ASHRAE 2007 suggests that an averaging time of 2 minutes corresponds to full-scale averaging time of one hour. In the present study, the averaging time for collecting samples was one minute since the syringe sampler was capable of collecting the $\mathrm{SF}_{6}$ samples in one minute. Previous studies carried out under similar experimental conditions by Saathoff et al. [4] and Stathopoulos et al. [2] have shown that this change in collection time (difference in one minute) did not affect the measurements significantly. Equivalent averaging time depends on model scale and wind speed. It is known that a wind tunnel plume spreads at a rate equivalent to half hour averages in the field. Additionally, in the absence of large diurnal and geophysical scales in the wind 
tunnel, after some model time all averages will be equivalent. Further discussion on time scales is available in Hajra et al. [10].

\subsection{Concentration measurements}

Tracer gas was released from rooftop stacks $\left(\mathrm{h}_{\mathrm{s}}\right)$ 1, 3 or $5 \mathrm{~m}$ high and $\mathrm{M}$ ranging from 1 to 3 . The gas consisted of a mixture of sulphur hexafluoride $\left(\mathrm{SF}_{6}\right)$ and nitrogen, which was released from a stack whose diameter was $3 \mathrm{~mm}$ representing a full scale value of 0.6 m. Concentration measurements were generally made once the wind tunnel was stable after about 5 minutes. A syringe sampler was connected to various receptors via tubings to collect $\mathrm{SF}_{6}$ samples. Previous studies by Saathoff et al. [22] showed that the efficient ventilation facility of the laboratory was sufficient to remove any background concentration of $\mathrm{SF}_{6}$ during the experiments. A VARIAN 3400 Gas Chromatograph (GC) with precision approximately 5\% and measurement resolution equal to one [26] was used to estimate the concentration of the syringe samplers. A few tests for the isolated cases $\left(\mathrm{B}_{1}\right.$ and $\left.\mathrm{B}_{6}\right)$ with flat roof were repeated in about two months following the completion of testing various downstream configurations. It was found that the measured concentrations on the rooftop were repeatable within $\pm 15 \%$ of previously recorded data, which is generally considered to be accurate for near-field dispersion studies.

\section{Results and discussion}

The results are presented and discussed into two subsections. At the outset, reliability of the wind tunnel data is discussed by comparing them with key previous studies.

\subsection{Reliability of wind tunnel data}

Prior to discussing the various results of this study, a comparison between results of the present study and some previous studies carried out by Schulman and Scire. [9] and Petersen et al. [27] is made to test the reliability of the wind tunnel data of the present study. Results are shown in Figure 5. 
Table 3 Experimental parameters used in the present and previous studies.

\begin{tabular}{|l|l|l|l|}
\hline $\begin{array}{l}\text { Experimental } \\
\text { parameters }\end{array}$ & $\begin{array}{l}\text { Present } \\
\text { study }\end{array}$ & $\begin{array}{l}\text { Schulman and } \\
\text { Scire. [9] }\end{array}$ & $\begin{array}{l}\text { Petersen et al. } \\
{[27]}\end{array}$ \\
\hline Model scale & $1: 200$ & $1: 100$ & $1: 50$ \\
\hline $\begin{array}{l}\text { Wind speed at } \\
\text { building height (m/s) }\end{array}$ & 6.2 & 1.37 & 4.0 \\
\hline Upstream terrain & Urban & Suburban & Suburban \\
\hline Power law exponent & 0.31 & 0.20 & 0.19 \\
\hline Stack diameter (m) & 0.6 & 0.75 & 0.40 \\
\hline Building height (m) & 15 & 15 & 15 \\
\hline Building width (m) & 50 & 75 & 15 \\
\hline Building breadth (m) & 50 & 75 & 30 \\
\hline
\end{tabular}

NB: Width refers to building dimension perpendicular to wind direction at $0^{\circ}$.

Although, there are important differences in the experimental conditions, as shown in Table 3, comparisons in dilution, especially at receptors further away from the stack, are very good. It is worth noting that although building heights are similar, the building used in the present study is larger and the exposure is urban, compared to suburban terrain used by Petersen et al. [27]. Results of the present study also compare well with wind tunnel data from Schulman and Scire [9], particularly beyond $15 \mathrm{~m}$ downwind of stack despite a suburban terrain used in that study. Regardless of these differences, the overall comparisons and trends of data are encouraging.

The subsequent sections discuss the effect of different building geometries placed downstream of the emitting building. Shorter downstream buildings do not affect the rooftop dilution on an emitting building since the plume structure remains unaffected. Similar observations were made by Wilson et al. [6] through water channel studies for some limited cases. Hence, the present study discusses taller downstream buildings and buildings of similar height as the emitting building, since these cases were found to be more critical. 


\subsection{Effect of a taller or similar downstream building}

The effects of a downstream building taller or of similar height with the emitting building are presented and discussed in this section. The concentrations were measured on the rooftop and leeward wall of emitting building, as well as on the windward wall and roof of the downstream building.

\subsubsection{Rooftop dilution on the emitting building}

The effects of placing a taller downstream building are presented in Figure 6. It may be noted that although, $B_{2}, B_{3}$ and $B_{4}$ are twice as tall as $B_{1}$, the along wind dimension of $B_{3}$ is half of $B_{2}$ and across wind dimension of $B_{4}$ is $60 \%$ of $B_{2}$ (see Table 1). Figure 6 (a) shows comparisons of Configurations 1 through 5, ASHRAE 2007 and ASHRAE 2011 in terms of normalised dilution on rooftop of emitting building $\left(B_{1}\right)$ for $h_{s}=1 \mathrm{~m}, M=1, S$ $=20 \mathrm{~m}$ and $\mathrm{X}=0$. It was observed that dilution predicted by Configurations 2 and 3 were comparable at all points. This is because most of the pollutants escape as side leakage with only a portion of the plume affecting the roof of the emitting building. Additionally, a change in along wind dimension of the downstream building makes the plume travel marginally more thereby keeping the rooftop dilution unchanged. However, Configuration 4 predicts higher dilution than Configurations 2 and 3 because a reduced across wind dimension gives more scope for the effluents to escape from the sides, thereby increasing rooftop dilution on the emitting building, although they are somewhat lower than the isolated case. Configuration 5 predicts about 10 times lower dilution than Configurations 2 and 3 owing to the height of the downstream building $\left(\mathrm{B}_{5}\right)$ which disallows the pollutants from escaping through the sides and upwash. ASHRAE 2011 compares well with experimental data close to the downwind edge of the building and up to about $15 \mathrm{~m}$ downwind of stack. This is primarily because the plume spread parameters described in equations 19 and 20, are mostly dependent on the terrain characteristics $\left(Z_{\mathrm{o}}\right)$ and height of the plume above rooftop $(Z)$ besides $d_{e}$ and $X$. It is understandable that $Z_{o}$ has an important role in influencing the near-field dispersion process, a fact that was not taken into account by ASHRAE 2007. The previous versions of ASHRAE based their calculations of plume spread on $\mathrm{M}$ values without considering the turbulence generated by the terrain. Very close to the stack ASHRAE 2011 predicts very low dilution possibly 
because the plume rise estimations are quite low. According to ASHRAE 2011 "Only jet momentum rise is used; buoyancy rise is neglected as a safety factor." The additional safety factor in plume rise estimation limits the plume rise thereby causing higher concentration predictions closer to the stack. A similar trend is observed at $h_{s}=1 \mathrm{~m}$ and $\mathrm{M}=3$, as shown in Figure 6 (b) although the dilution for Configurations 4 and 1 become comparable, especially at receptors close to the downwind edge of $\mathrm{B}_{1}$ because higher exhaust speeds and smaller across wind dimension of the downstream building enhances greater plume spread to reduce the effect of the downstream building. At greater $h_{s}$ and $M$ values the dilution predicted by Configurations 2, 3 and 4 become comparable to the isolated case as shown in Figures 6 (c) and 6 (d). However, ASHRAE 2011 predicts about 5 times higher dilution than wind tunnel data for $\mathrm{h}_{\mathrm{s}}=3 \mathrm{~m}$ and $\mathrm{M}=1$ (Figure 6 (c)), possibly because the spread parameters over predict plume spread at lower $M$ values making it necessary to re-visit these formulations. ASHRAE 2007 predicts lower dilution than all configurations for any $h_{s}$ and $M$ value because its formulations do not account for turbulence generated due to adjacent buildings and local topography.

For buildings of similar height, Figure 7 (a) shows comparisons for Configurations 1a through 4a, ASHRAE 2007 and ASHRAE 2011 in terms of normalised dilution on rooftop of $\mathrm{B}_{6}$ for $\mathrm{h}_{\mathrm{s}}=1 \mathrm{~m}, \mathrm{M}=1$ and $\mathrm{X}=0$. As mentioned previously, Configurations $2 \mathrm{a}$ and $3 a$ have $B_{2}$ and $B_{3}$ downstream of $B_{6}$ respectively with the along wind dimension of the former twice as much as the latter. Configurations $2 \mathrm{a}$ and $3 \mathrm{a}$ predict comparable dilution at all receptors which shows that a change in along wind dimension does not produce significant change in rooftop dilution on the emitting building. However, Configuration $4 \mathrm{a}$ predicts higher dilution than Configurations $2 \mathrm{a}$ and $3 \mathrm{a}$ owing to increased side-leakage. In general, the dilution predicted by all the configurations is lower than the isolated case. This trend remains almost unchanged for $h_{s}=1 \mathrm{~m}$ and $\mathrm{M}=$ 3, as shown in Figure 7 (b) although the dilution is somewhat higher than that found for $\mathrm{M}=1$. Also at some points closer to the downwind edge of emitting building, dilution predicted by all configurations are comparable to the isolated case. ASHRAE 2007 predicts lower dilution for all cases, thus it is overly conservative. For higher $h_{s}$ and $M$ the dilution generated by all configurations were found to be comparable to the isolated case indicating the reduced effects of the downstream building. A similar trend was also 
observed for a stack placed at $\mathrm{X}=20 \mathrm{~m}$ possibly because of greater plume spread and since the downstream building is of equal height as the source, thereby reducing the possibility of plume meandering. ASHRAE 2011 predicts comparable dilution at $\mathrm{h}_{\mathrm{s}}=1 \mathrm{~m}$ and $\mathrm{M}=1$ at all receptors beyond $15 \mathrm{~m}$ downwind of stack whilst a greater departure between ASHRAE 2011 predictions and experimental data within 25m downwind of stack, were observed at $\mathrm{h}_{\mathrm{s}}=1 \mathrm{~m}$ and $\mathrm{M}=3$.

\subsubsection{Dilution on the leeward wall of the emitting building}

The plume geometry affects the leeward wall of the emitting building $\left(B_{1}\right)$ at low $h_{s}$, as shown in Figure 8 (a) where comparable dilution for Configurations 2 and 3 was obtained because the across-wind building dimensions are equal. Additionally, the plume released from the stack travels the same distance for Configurations 2 and 3. It is not surprising that no plume concentrations were found on the leeward wall of $\mathrm{B}_{1}$ for Configuration 4 due to the side leakage phenomenon explained previously. Lower dilution was observed for Configuration 5 compared to Configurations 2 and 3 since the plume was trapped within the recirculation length of $\mathrm{B}_{1}$ partly due to low exhaust speed and partly due to the back-and-forth movement (meandering) of the plume owing to the greater height of the downstream building $\left(\mathrm{B}_{5}\right)$. Similar observations were found at $\mathrm{M}=$ 2, as shown in Figure 8 (b) although the dilution was higher by about a factor of 8 due to greater M. For $h_{s}>1 \mathrm{~m}$ no plume concentrations were found since the plume rise is sufficiently high to allow it to escape the zone of recirculation in the wake of the emitting building. Additionally, when the stack was moved to $X=20 \mathrm{~m}$, no plume concentrations were found on the leeward wall of the emitting building as most of the pollutants would affect the roof of the emitting building. For buildings of similar height, pollutants mostly affected the roof of both buildings and hence no effluent concentration on the leeward wall of the emitting building was found. ASHRAE 2007 and 2011 do not provide dilution values for building walls.

\subsubsection{Dilution on the windward wall of the downstream building}

Figure 9 (a) shows comparisons of results of Configurations 2, 3 and 4 for $h_{s}=1 \mathrm{~m}$, $\mathrm{M}=1$ and $\mathrm{X}=0$. Comparable dilution for Configurations 2 and 3 was obtained since a 
change in along wind dimension of the downstream building has negligible effect on the distance travelled by the airborne pollutant. It may be noted that the dilution is somewhat lower closer to the ground than near the upper wall, possibly due to the deposition of effluents on the ground after striking the wall. Side leakage results in no deposition of pollutants on the windward wall of the downstream building for Configuration 4. A similar trend is observed at $h_{s}=1 \mathrm{~m}$ and $M=3$ as shown in Figure $9(\mathrm{~b})$, although the dilution is about 10 times higher than that obtained at $\mathrm{M}=1$ due to greater exhaust speeds. At $h_{\mathrm{s}}>1 \mathrm{~m}$ zero concentrations (within the measurement resolution of the instrument) were found on the windward wall possibly because of greater plume rise which allows the plume to disperse more. When the stack is centrally placed the trends remain unchanged although the dilution is somewhat higher than at $\mathrm{X}=0$ due to greater plume spread. Configuration 5, which consisted of a downstream building $\left(\mathrm{B}_{5}\right)$ almost four times as tall as the emitting building (see - Figure 4) also showed similar trends as Configurations 2 and 3 although the dilution was somewhat lower for corresponding values of $h_{s}$ and $M$ owing to the greater height of $B_{5}$.

Similar trends were observed for buildings of similar height although the dilution was somewhat higher than that obtained for downstream buildings twice as high as the emitting building. Expectedly, zero concentrations (again, within the measurement resolution of the instrument) were obtained for Configuration $4 \mathrm{a}$ owing to a narrow downstream building.

\subsubsection{Dilution on rooftop of downstream building}

Figure 10 (a) shows normalised dilution on the roof of $\mathrm{B}_{3}$ for $\mathrm{h}_{\mathrm{s}}=1 \mathrm{~m}, \mathrm{M}=1$ and $\mathrm{X}=$ 0 for Configuration 3. This was chosen because the dilution trends were found to be similar to Configuration 2; indeed a slightly longer downstream building would not change the overall plume structure. Although the dilution was somewhat low for $\mathrm{M}=1$, a marginal increase was observed for $\mathrm{M}=2$ and $\mathrm{M}=3$ respectively. Considering the height of the emitting building is half of that of the downwind building, plume rise is not sufficient for the pollutants to affect the roof of the downstream building. Also, since most part of the plume affects the roof of the emitting building and escapes through side leakage, a smaller share of the effluents accumulate on the roof of the downstream 
building due to upwash, leading to higher dilution. A similar observation was made for $\mathrm{h}_{\mathrm{s}}$ $=3 \mathrm{~m}$ as shown in Figure 10 (b). In fact an increase in $\mathrm{h}_{\mathrm{s}}$ produced negligible change in dilution on $\mathrm{B}_{3}$ possibly because the amount of pollutants deposited on the roof of $\mathrm{B}_{3}$ was negligible. At $h_{s}>3 \mathrm{~m}$ no effluent concentrations were found due to greater plume spread. A similar trend was also observed for a stack placed at $X=20 \mathrm{~m}$ although the dilution was somewhat higher than that observed at $X=0$ for the respective $h_{s}$ and $M$ values.

For buildings of similar height, comparable dilution in Configurations $2 \mathrm{a}, 3 \mathrm{a}$ and $4 \mathrm{a}$ were obtained on the rooftop of the downstream building for low stacks $\left(\mathrm{h}_{\mathrm{s}}=1 \mathrm{~m}\right)$ at a given stack location, although they increased marginally for higher $M$ values, a trend similar to the taller downstream cases. ASHRAE formulations cannot be used to estimate pollutant concentrations on rooftop of downstream building.

\subsubsection{Dilution on rooftop of emitting building for centrally-placed stacks}

Figure 11 (a) shows normalised dilution on rooftop of the emitting building $\left(\mathrm{B}_{1}\right)$ for $\mathrm{h}_{\mathrm{s}}=1 \mathrm{~m}, \mathrm{M}=1$ and $\mathrm{X}=20 \mathrm{~m}$. It was observed that Configurations 2 and 3 predict comparable dilution at all downwind receptors although they are somewhat lower than the isolated case by about a factor of 2. Configuration 4 compares well with the isolated case at all receptors because the side leakage phenomenon is more pronounced to disperse the effluents from the sides of the building thereby reducing the effect of the downstream building. However, Configuration 5 continued to predict lower dilution than the isolated case. A similar trend is observed at $\mathrm{h}_{\mathrm{s}}=1 \mathrm{~m}$ and $\mathrm{M}=3$ as shown in Figure 11 (b), although the dilution was somewhat higher for all cases due to increased plume spread. In fact dilution predicted for Configurations 2 and 3 are comparable to the isolated case especially at receptors close to the downwind edge of the emitting building. This also suggests that with increased stack height and $M$ the effect of the downstream building gradually diminishes. It is not surprising that the dilution produced by all configurations becomes comparable to the isolated case for a given $M$ at $h_{s}>1 \mathrm{~m}$. ASHRAE 2007 continues to predict lower dilution for all configurations whilst ASHRAE 2011 predicts higher dilution than the experimental data at all receptors irrespective of $h_{s}$ and M. As the stack is moved to the centre of the roof, the plume affects the receptors 
immediately downwind the stack at low exhaust speed and low stack height due to increased downwash; although this effect gradually reduces with increased $M$ [9]. ASHRAE 2011 uses the equations of Cimoreli et al. [15] to calculate plume spread, which does not incorporate the effect of stack location and downwash at lower values of M.

Similar trends were observed for buildings of similar height. As the stack is placed closer to the centre of the emitting building, the effect of the downstream building is greatly reduced resulting in comparable dilution for all configurations with the isolated case.

\subsubsection{Effect of spacing between buildings}

Figure 12 (a) shows the effect of spacing between the buildings for Configuration 2 at $\mathrm{h}_{\mathrm{s}}=1 \mathrm{~m}$ and $\mathrm{M}=1$. It was observed that at $\mathrm{S}=20 \mathrm{~m}$ and $\mathrm{S}=25 \mathrm{~m}$ comparable dilution were obtained on the windward wall of the downstream building $\left(\mathrm{B}_{2}\right)$. This is because despite the side leakage phenomenon, a part of the plume remains trapped within the wake of the emitting building and most of the particles strike the windward wall of the downstream building. As a result, an additional spacing of $5 \mathrm{~m}$ makes the plume travel a very small distance downwind resulting in comparable dilution for $\mathrm{S}=20 \mathrm{~m}$ and $\mathrm{S}=25$ $\mathrm{m}$. However, when the buildings are moved further apart at $\mathrm{S}=30 \mathrm{~m}$, there is increased side leakage resulting in higher dilution (almost 10 times higher) than at $\mathrm{S}=20 \mathrm{~m}$. In fact, at $\mathrm{S}>30 \mathrm{~m}$ "zero concentration" was found on the windward wall of $\mathrm{B}_{2}$ suggesting that the effect of downstream building was greatly reduced. It may also be noted that the recirculation length of the emitting building $\left(B_{1}\right)$ is $22.3 \mathrm{~m}$ as per ASHRAE 2007 and dilution on windward wall of $\mathrm{B}_{2}$ were found to be comparable when the buildings were placed within this region. An almost similar trend is observed at $h_{s}=1 \mathrm{~m}$ and $\mathrm{M}=3$ as shown in Figure 12 (b), although the dilution was found to be somewhat higher than at M $=1$. It is also worth noting that the "zero concentration" found at $\mathrm{S}=30 \mathrm{~m}$ and beyond, is possibly due to the greater plume spread at higher $\mathrm{M}$.

Comparable dilution at $\mathrm{S}=20 \mathrm{~m}$ and $\mathrm{S}=25 \mathrm{~m}$ were found on rooftop of $\mathrm{B}_{1}$ for Configuration 2 at $h_{s}=1 \mathrm{~m}, \mathrm{M}=1$ and $\mathrm{X}=0$, as shown in Figure 13 (a) although the dilution was somewhat lower than the isolated case. These trends were similar to those 
observed for windward wall of $\mathrm{B}_{2}$, as explained previously. However, at $\mathrm{S}=30 \mathrm{~m}$ comparable dilution was obtained with the isolated case. Similar trends were also observed at $h_{s}=1 \mathrm{~m}$ and $\mathrm{M}=3$, as shown in Figure 13 (b) although the dilution was somewhat higher than for respective values at $\mathrm{M}=1$. ASHRAE 2007 and ASHRAE 2011 predictions are always for isolated building cases, so these values are used here only for references.

For buildings of similar height, irrespective of stack height, stack location and $\mathrm{M}$, as spacing exceeds the recirculation length of the emitting building, rooftop dilution on the emitting building becomes comparable to the isolated case, whilst the plume does not affect the downstream building surface since the pollutants get enough scope to disperse through the air.

\section{Design guidelines}

This section presents a summary of findings and provides design guidelines based on tracer gas experiments in the wind tunnel for a taller (or similar height) building placed downstream of the emitting building:

\subsection{Summary of findings}

\section{Effect of building size}

1. A change in along wind dimension of the downstream building does not alter dilution on building surfaces significantly.

2. For a given stack location, a narrow downstream building allows greater dispersion of the plume thereby increasing rooftop dilution on the emitting building.

3. For buildings of equal width and stack located at the upwind edge, rooftop dilution on the downstream building remains constant for low stack heights, irrespective of $\mathrm{M}$; centrally-placed stacks allow greater dispersion of the plume, thereby affecting less the downstream building surfaces.

4. A downstream building more than twice as tall as the emitting building prevents the plume from escaping and hence generates lower dilution on the rooftop of emitting building than the isolated case. 
5. Dilution from all downstream configurations of similar height is comparable with that of the isolated building case for centrally-placed stacks at any given $\mathrm{h}_{\mathrm{s}}$ and $\mathrm{M}$.

\section{Effect of spacing $(\mathrm{S})$ between the buildings}

1. When a taller downstream building is placed within the recirculation length of the emitting building $\left(\mathrm{L}_{\mathrm{r}}\right)$, higher dilution was measured on both building surfaces for low stacks located at the upwind edge with increased $M$ values.

2. At distances greater than $\mathrm{L}_{\mathrm{r}}$, no pollutant concentrations were found on the taller downstream building irrespective of $\mathrm{h}_{\mathrm{s}}$ and $\mathrm{M}$.

3. Spacing between buildings was found to be less critical for buildings of similar height as compared to taller downstream buildings; rooftop dilution was generally found to be comparable to the isolated building case for any given $h_{s}$ and $M$.

\section{$\underline{\text { ASHRAE }}$}

1. ASHRAE 2007 generally predicts lower dilution for all building configurations because it assesses plume dilution by considering the windward wall dimensions of the emitting building. The predictions of ASHRAE 2007 were found to be overly conservative.

2. ASHRAE 2011 generally predicts higher dilution than experimental data for the isolated cases leading to un-conservative estimates.

In general, ASHRAE cannot be used to estimate dilution on building walls and adjacent building surfaces.

\subsection{Design guidelines}

Based on the results of this study the following design guidelines for the placement of stack and intake in order to avoid, or at least minimise, plume re-ingestion are made:

\section{Taller or similar downstream building}

1. Regardless of the distance (S) between the buildings, intakes may be placed upwind of stack and closer to the leeward wall of the downstream building. 
2. When downstream buildings are placed within the recirculation length of the emitting building i.e $\mathrm{S}<\mathrm{L}_{\mathrm{r}}$, intakes should not be placed on rooftop locations downwind of a low stack and the leeward wall of emitting building as shown schematically in Figure 14 (a); intakes should not also be placed on the windward wall and roof of the downstream building.

3. When $\mathrm{S}>\mathrm{L}_{\mathrm{r}}$, intakes may be placed anywhere on either building (see Figure 14 (b)). The figure clearly shows that whilst the plume is engulfed within the recirculation region of the emitting building, pollutant re-entry into the source and downstream building is possible through the walls. However, increased spacing between buildings greatly reduces this possibility.

\section{Conclusions}

Wind tunnel results from a micro-scale pollutant dispersion study on downstream building effects are presented. The study shows that for two buildings of equal across wind dimension, the height and spacing between buildings affects the pollutant dispersion process. When a downstream building is placed beyond the recirculation zone of the emitting building, the effects of the downstream building on dilution of exhaust gradually reduce. For any given stack height and exhaust speed, intakes can be placed upwind of stack on the emitting building and closer to the leeward walls of the downstream building since these areas are less affected by the plume. Current ASHRAE provisions are unconservative and must be re-visited. In particular, new formulations to assess plume dilution on adjacent building surfaces by taking into account turbulence due to neighbouring buildings must be emphasised.

\section{Acknowledgements}

The authors are thankful to the Institut de recherche Robert-Sauvé en santé et en sécurité du travail (IRSST), Montreal, Canada for funding this research.

\section{References}

[1] Schwartz J. Air pollution and daily mortality: A review and meta analysis. Journal of Environmental Research 1994; 64: 36-52. 
[2] Stathopoulos T, Hajra B, Bahloul A. Analytical evaluation of dispersion of exhaust from rooftop stacks on buildings. IRSST research report R-576, Montreal, Canada; Institut de recherche Robert-Sauvé en santé et en sécurité du travail; 2008.

[3] Kesarkar A, Dalvi M, Kaginalkar A, Ojha A. Coupling of the weather research and forecasting model with AERMOD for pollutant dispersion modelling. A case study for PM10 dispersion over Pune, India. Atmospheric Environment 2007; 41: 1976-1988.

[4] Saathoff P, Gupta A, Stathopoulos T, Lazure L. Contamination of fresh air intakes due to downwash from a rooftop structure. Journal of Air \& Waste Management Association 2009; 59: 343-353.

[5] Li W.W, Meroney R.N. Gas Dispersion near a cubical model building. Part II concentration fluctuation measurements. Journal of Wind Engineering and Industrial Aerodynamics 1983; 12: 35-47.

[6] Wilson D. J, Fabris I, Ackerman M Y. Measuring adjacent effects on laboratory exhaust stack design. ASHRAE Transactions 1998; 88 (1): 513-533.

[7] ASHRAE. Building air intake and exhaust design. ASHRAE applications handbook. Chapter 45. Atlanta, USA: American Society of Heating, Refrigerating and AirConditioning Engineering Inc.; 2011.

[8] Wilson D.J. Flow patterns over flat roofed buildings and application to exhaust stack design. ASHRAE Transactions 1979; 85: 284-295.

[9] Schulman L, Scire J. Effect of stack height, exhaust speed, and wind direction on concentrations from a rooftop stack. ASHRAE Transactions 1991; 77: 573-585.

[10] Hajra B, Stathopoulos T, Bahloul A. The effect of upstream buildings on near-field pollutant dispersion in the built environment. Atmospheric Environment 2011; 45: 49304940.

[11] Chavez M, Hajra B, Stathopoulos T, Bahloul A. Near-field pollutant dispersion in the built environment by CFD and wind tunnel simulations. Journal of Wind Engineering and Industrial Aerodynamics 2011; 99 (4): 330-339.

[12] Petersen R.L, Cochran B.C, Carter J.J. Specifying exhaust and intake systems. ASHRAE Journal 2002; 4: 30-35. 
[13] ASHRAE. Building air intake and exhaust design. ASHRAE applications handbook. Chapter 44. Atlanta, USA: American Society of Heating, Refrigerating and AirConditioning Engineering Inc.; 2007.

[14] Briggs G.A. Plume rise and buoyancy effects in atmospheric sciences and power production. D. Randerson, ed. DOE/TIC-27601 (DE 84005177), Washington, DC, USA: US Department of Energy; 1984.

[15] Cimoreli A.J, Perry S.G, Venkatram A, Weil J.C, Paine R.J, Wilson R.B, Lee R.F, Peters W.D, Brode R.W. AERMOD: A dispersion model for industrial source applications. Part I: General model formulation and boundary layer characterisation. Journal of Applied Meteorology 2005; 44: 682-693.

[16] ASHRAE. Airflow around Buildings. ASHRAE applications handbook. Chapter 24. Atlanta, USA: American Society of Heating, Refrigerating and Air-Conditioning Engineering Inc.; 2009.

[17] Turbulent Flow Instrumentation. Series 100 Cobra Probe Manual, Turbulent Flow Instrumentation 2008, pages 1-13.

[18] ESDU. Characteristics of atmospheric turbulence near the ground. Engineering Science Data Unit, no. 74030 and 74031, London, UK; 1974.

[19] Liu G, Xuan J, Park S. A new method to calculate wind profile parameters of the wind tunnel boundary layer. Journal of Wind Engineering and Industrial Aerodynamics 2003; 91: 1155-1162.

[20] Fackrell J.E, Pearce J.E. Parameters affecting dispersion in the near wake of buildings, CEGB report RD/M/1179/N81; 1981.

[21] Stathopoulos T. Design and fabrication of a wind tunnel for building aerodynamics. Journal of Wind Engineering and Industrial Aerodynamics 1984; 16: 361-376.

[22] Saathoff P, Stathopoulos T, Dobrescu M. Effects of model scale in estimating pollutant dispersion near buildings. Journal of Wind Engineering and Industrial Aerodynamics 1995; 54: 549-559.

[23] Counihan J. Adiabatic atmospheric boundary layers: A review and analysis of data from the period 1880-1972. Atmospheric Environment 1975; 9: 871-905.

[24] ESDU. Characteristics of atmospheric turbulence near the ground. Part I: definitions and general information, no. 74030, London, UK; 1976. 
[25] Snyder W. H. Guidelines for fluid modelling of atmospheric diffusion. EPA office of Air quality, planning and standards, Research Triangle Park, USA, EPA-600/8-81-009; 1981.

[26] Stathopoulos T, Lazure L, Saathoff P, Gupta A. The effect of stack height, stack location and rooftop structures on air intake contamination: A laboratory and full-scale study. Research report (R-392), Institut de recherché Robert Sauvé en santé et en sécurité du travail (IRSST), Montreal, Canada ; 2004.

[27] Petersen RL, Carter J.J, Ratcliff M. Influence of architectural screens on rooftop concentrations due to effluent from short stacks. ASHRAE Transactions 1999; 105: 2334. 


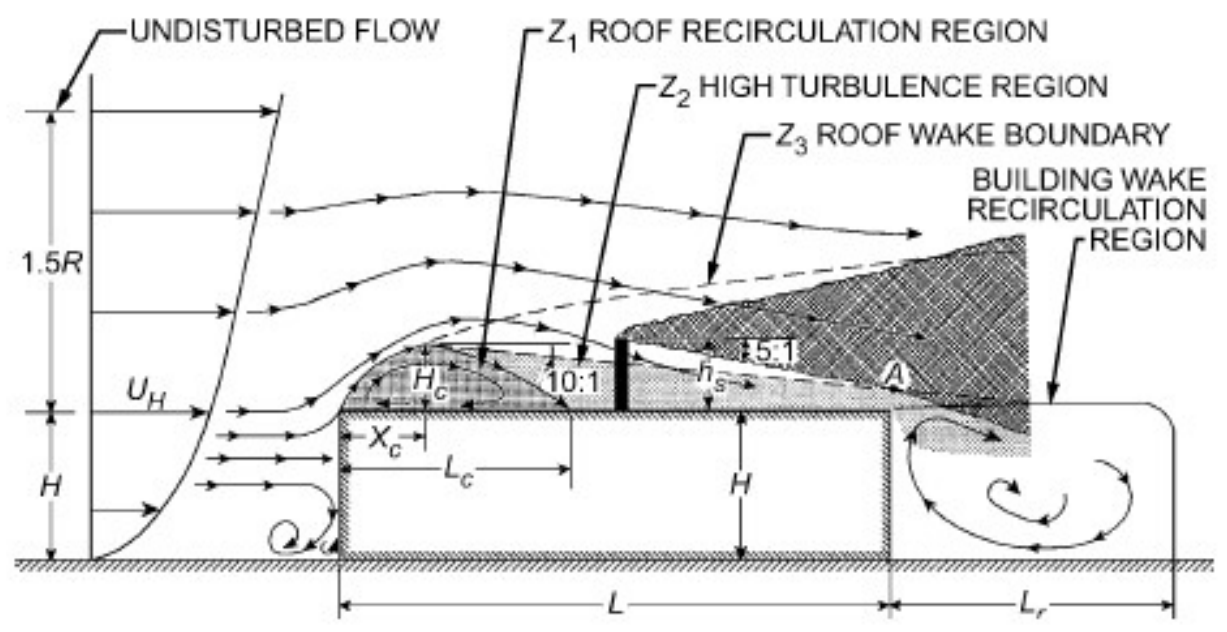

Figure 1. Design procedure for required stack height to avoid contamination (from Wilson. [8])

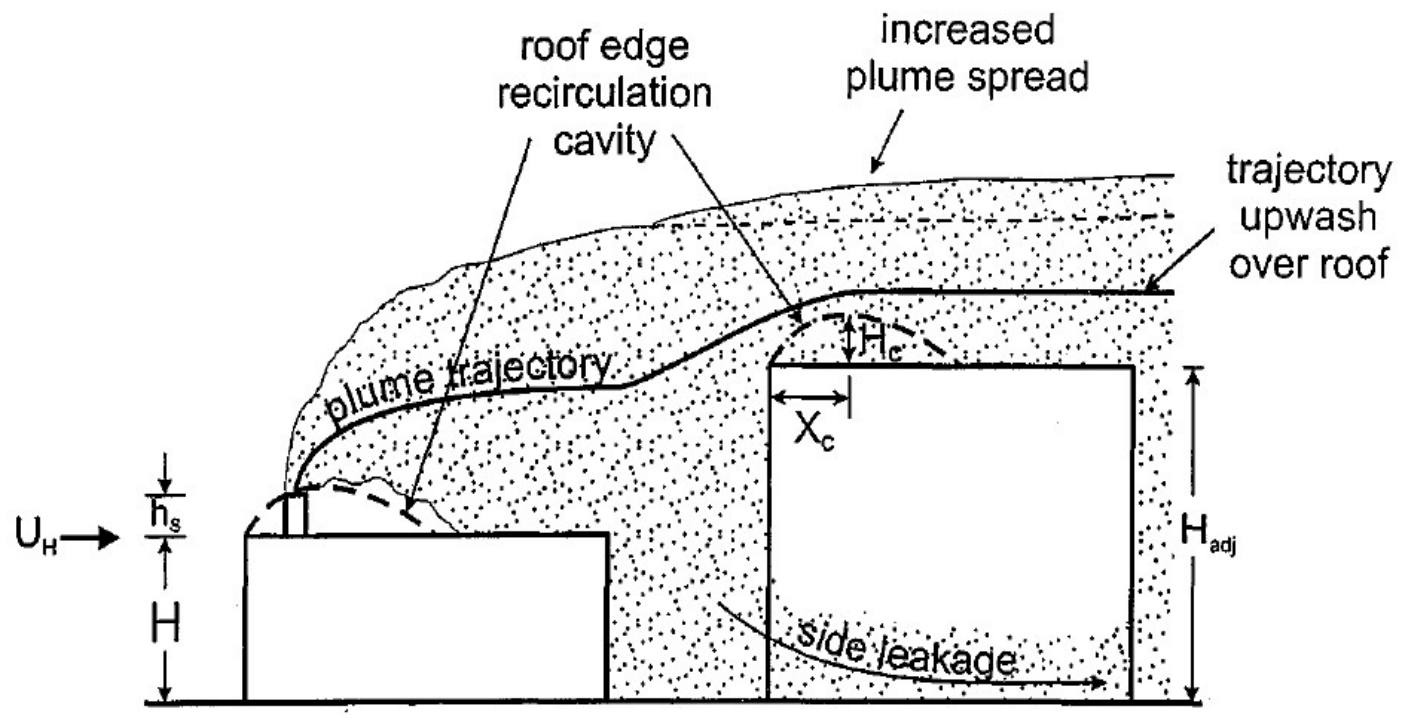

Figure 2. Side leakage phenomenon for taller downstream building (from Wilson et al. [6]) 

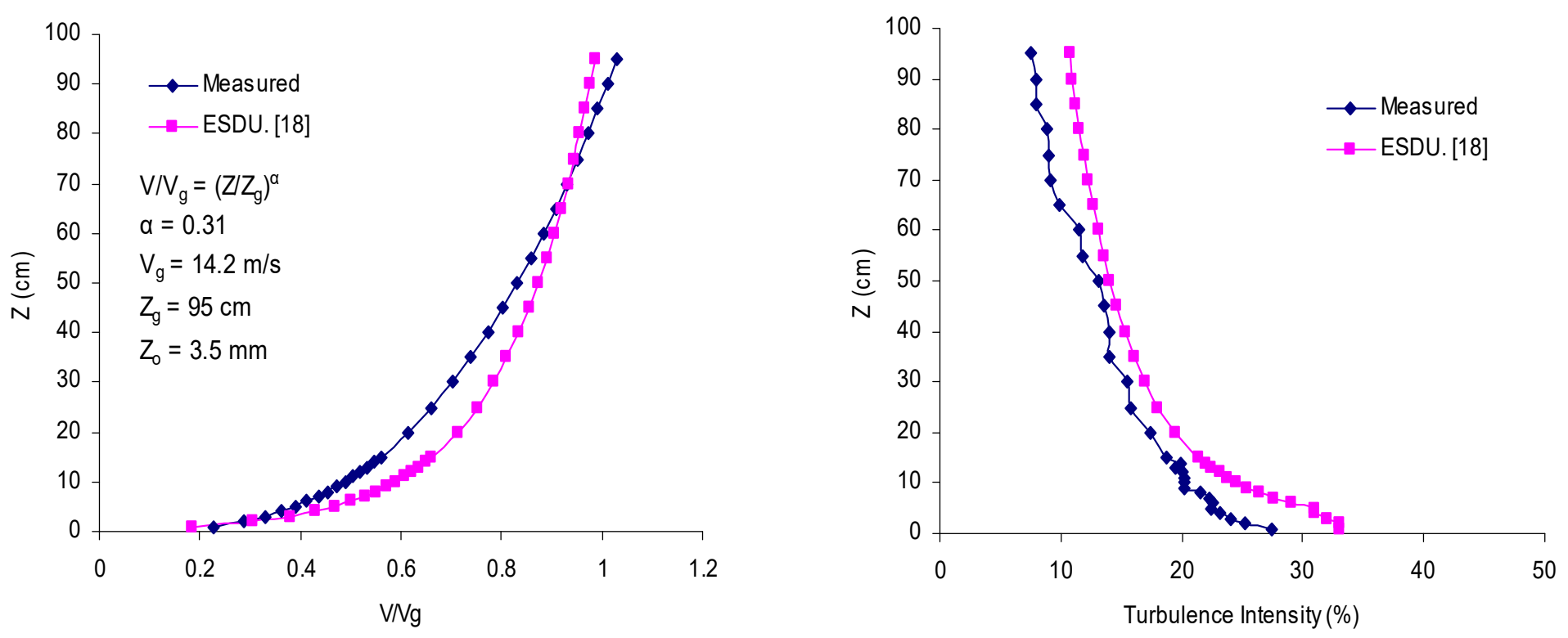

Figure 3 Mean velocity and turbulence intensity profiles measured at the Boundary Layer Wind Tunnel of Concordia University. 

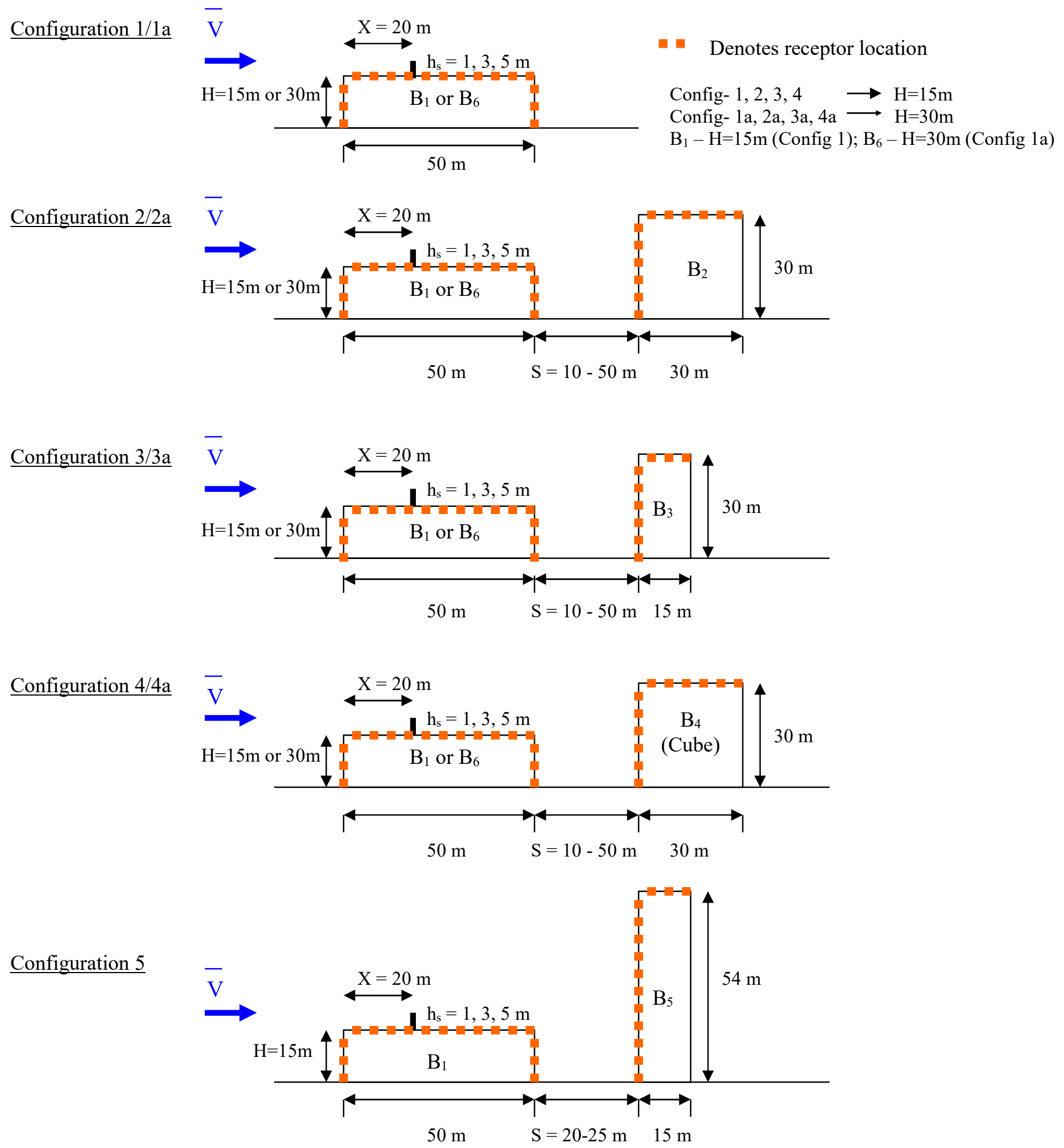

Figure 4: Buildings of various geometries downstream of a low or intermediate emitting building 


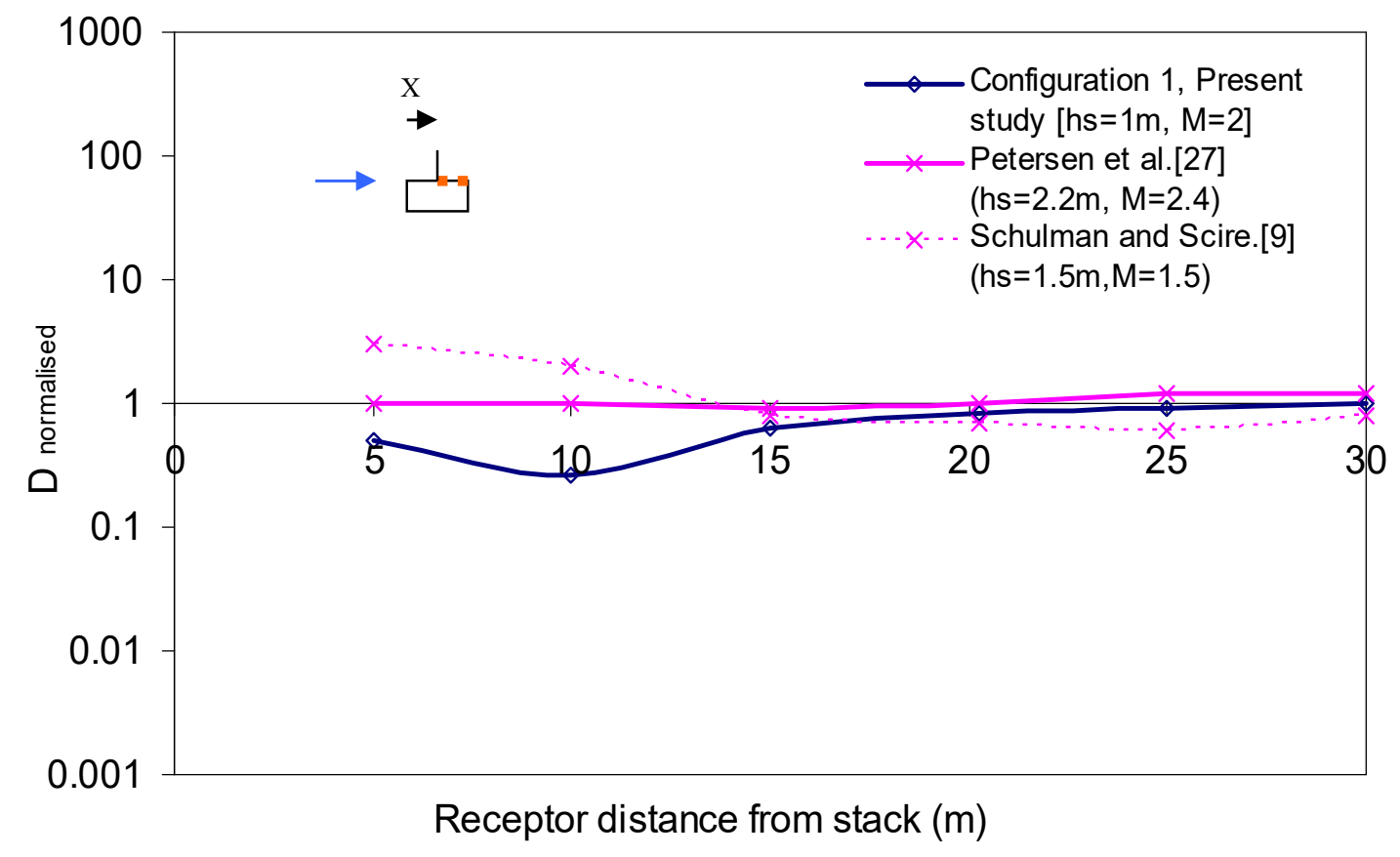

Figure 5. Comparison of wind tunnel measured normalised dilution and those from previous studies for Configuration 1 (isolated building) 
$h_{\mathrm{s}}=1 \mathrm{~m}, \mathrm{M}=1$

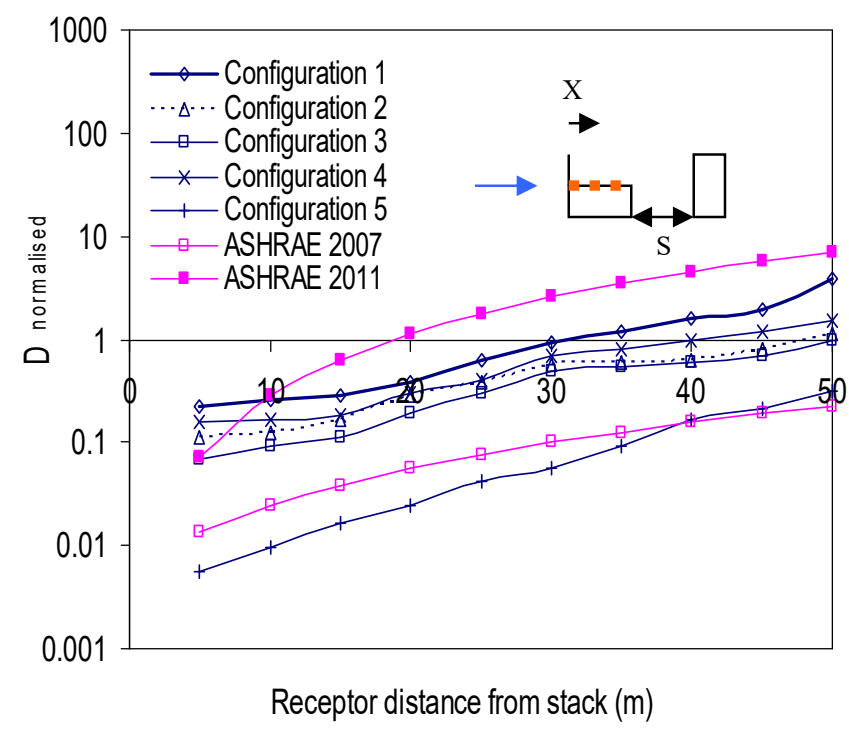

a)

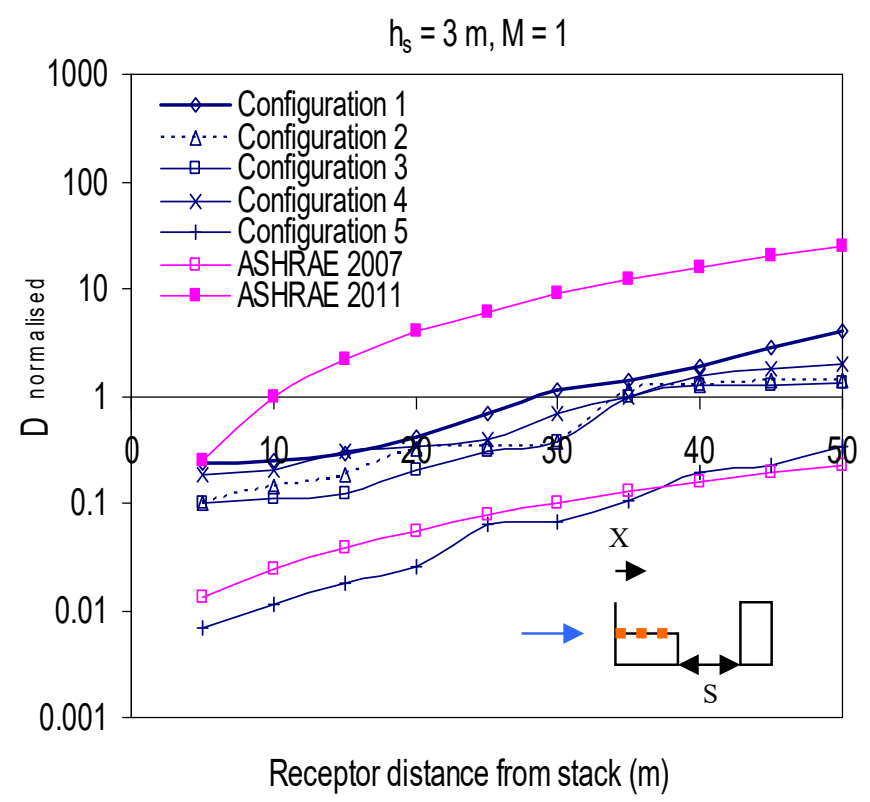

c)

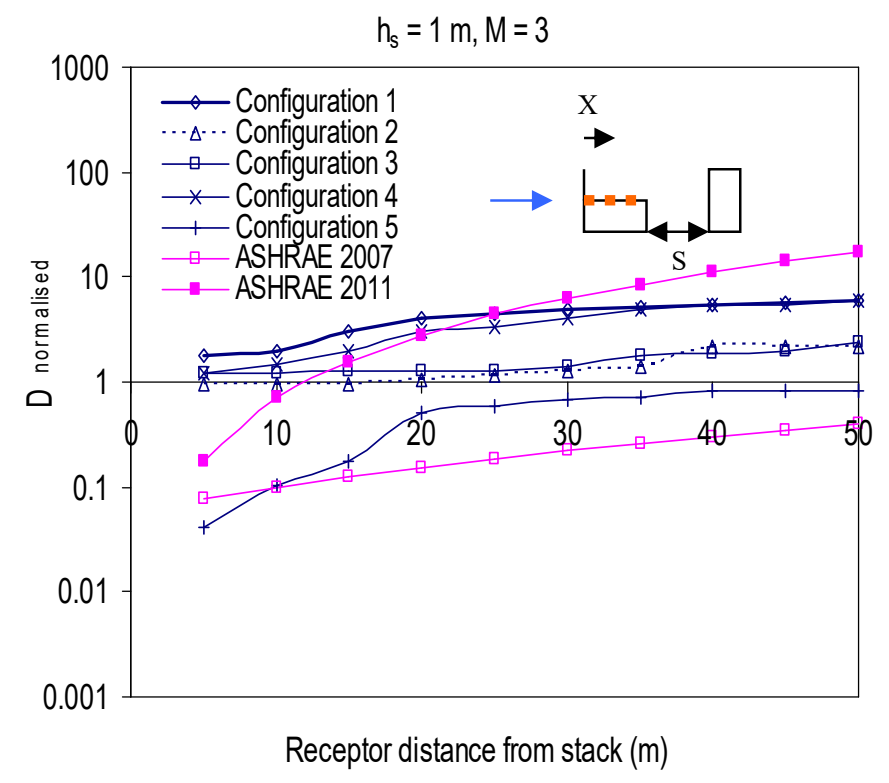

b)

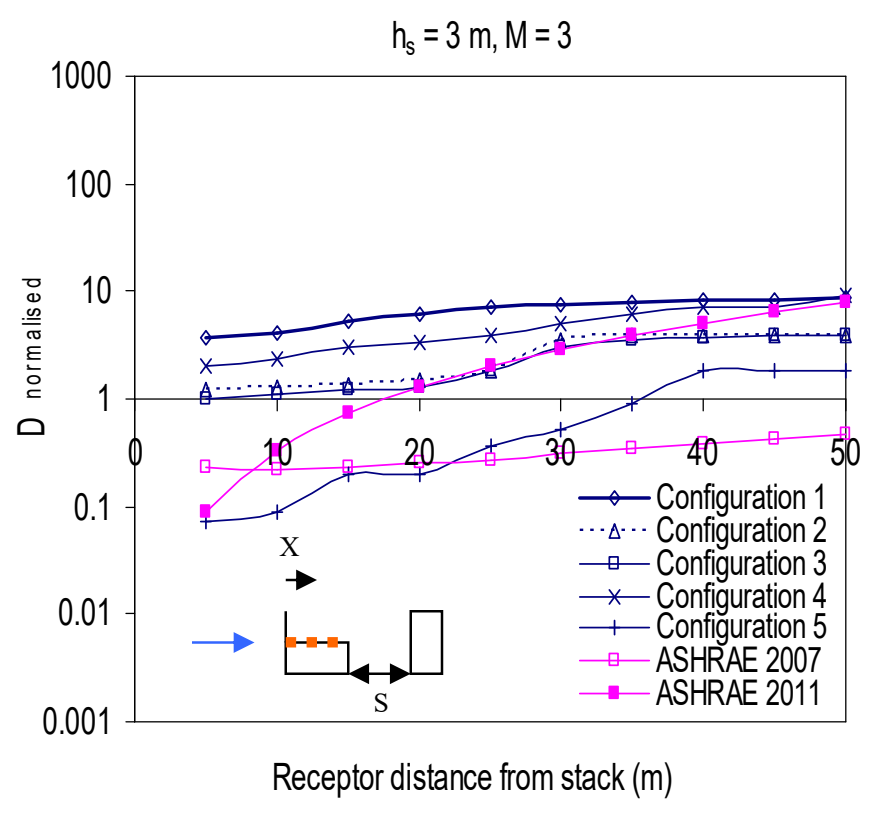

d)

Figure 6. Normalised dilution on rooftop of $B_{1}$ for $X=0$ and $S=20 \mathrm{~m}$ : a) $h_{s}=1 \mathrm{~m}, M=$ 1 ; b) $h_{s}=1 \mathrm{~m}, M=3$; c) $h_{s}=3 \mathrm{~m}, M=1$; d) $h_{s}=3 \mathrm{~m}, M=3$ 


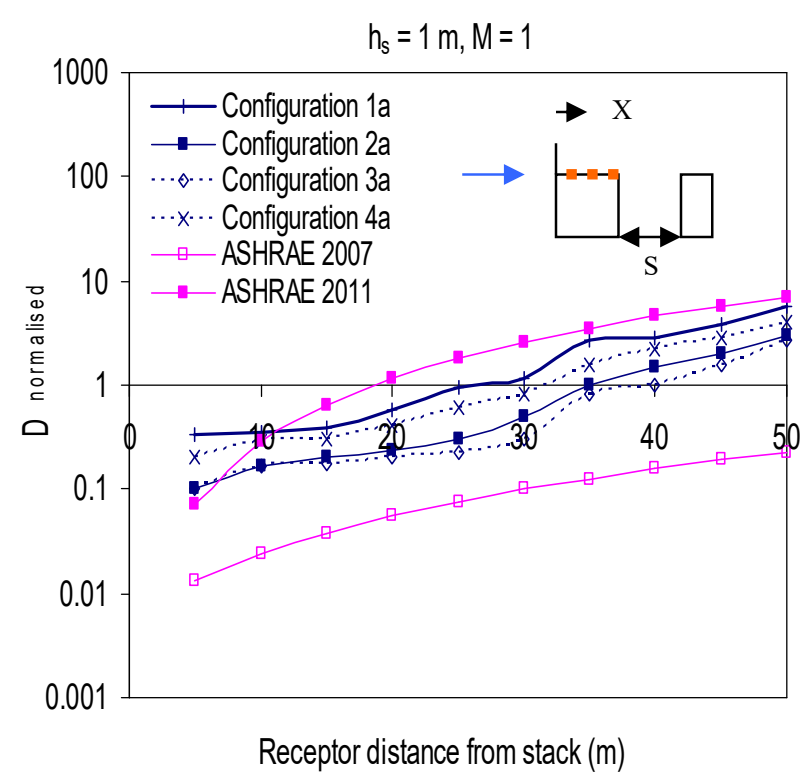

a)

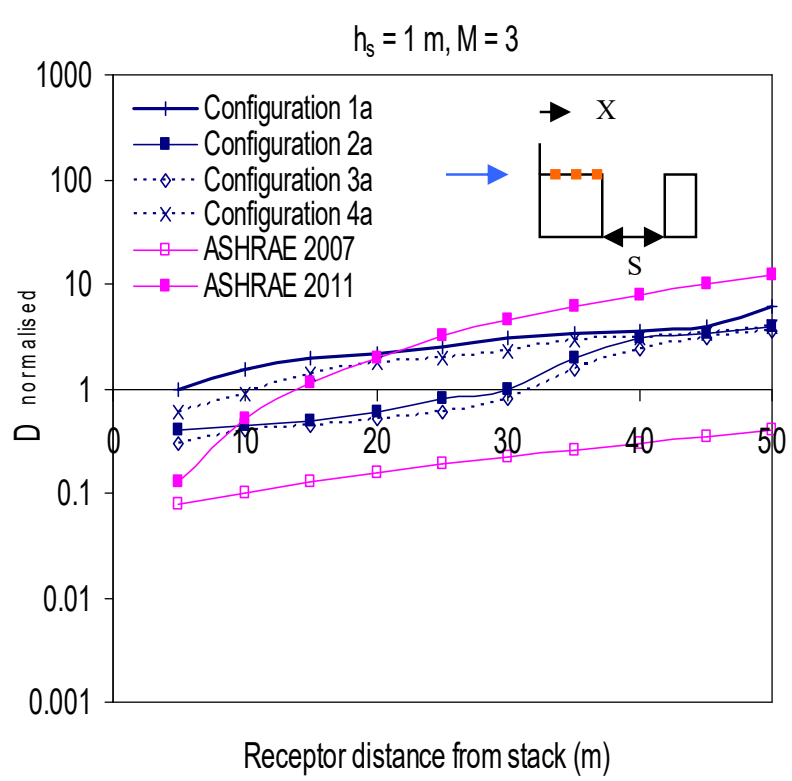

b)

Figure 7. Normalised dilution on rooftop of $B_{6}$ for $X=0$ and $S=20 \mathrm{~m}$ : a) $M=1$; ) $M=$ 3

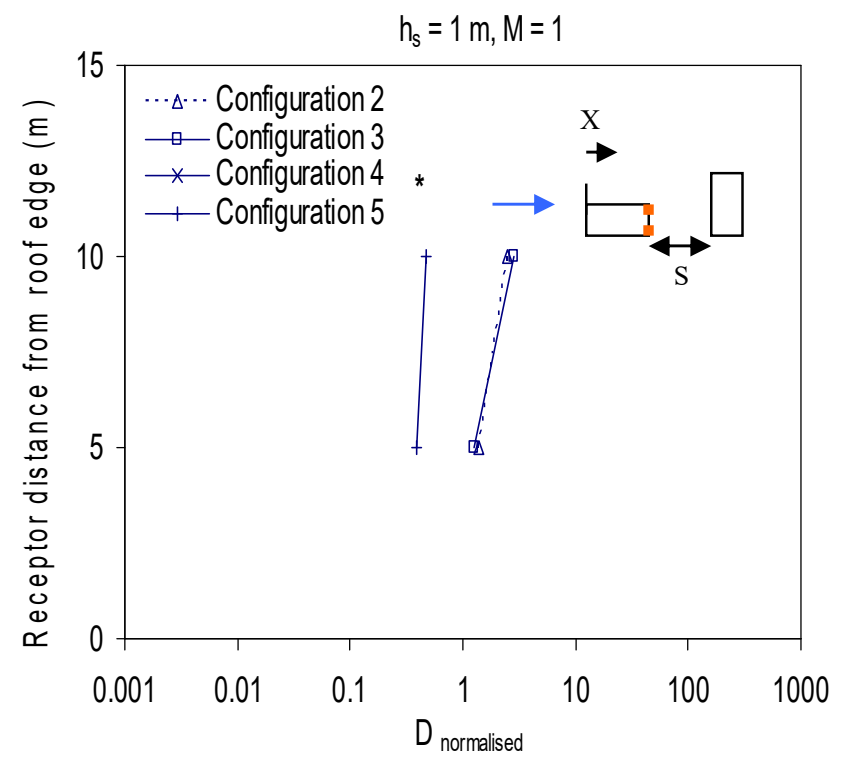

a)

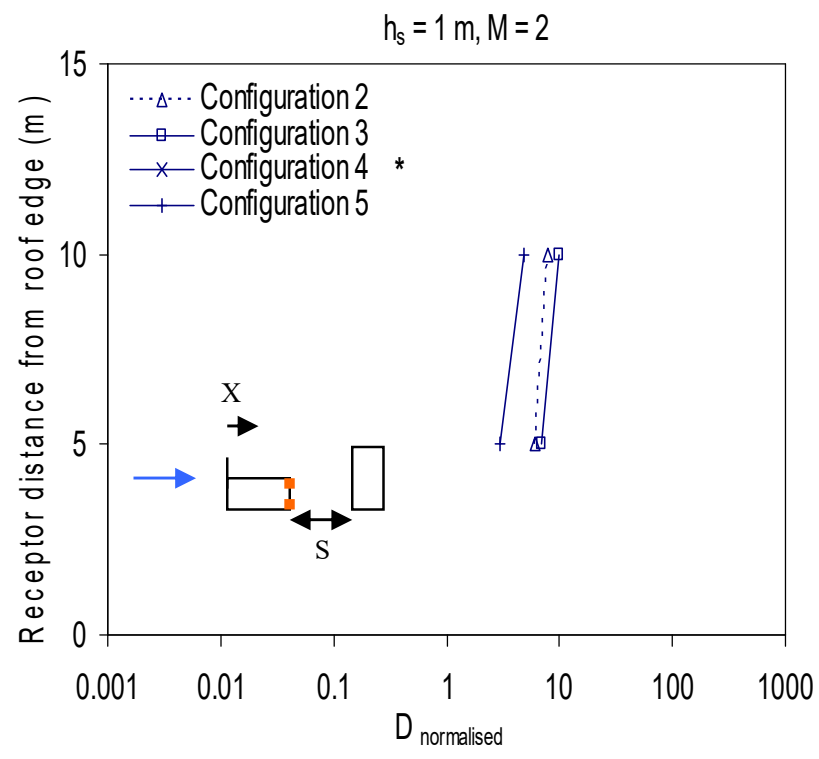

b)

Figure 8. Normalised dilution on leeward wall of $B_{1}$ for $X=0$ and $S=20 \mathrm{~m}$ : a) $M=1$; ) $\mathrm{M}=2$ (* Concentration of pollutant was measured zero at all receptors) 


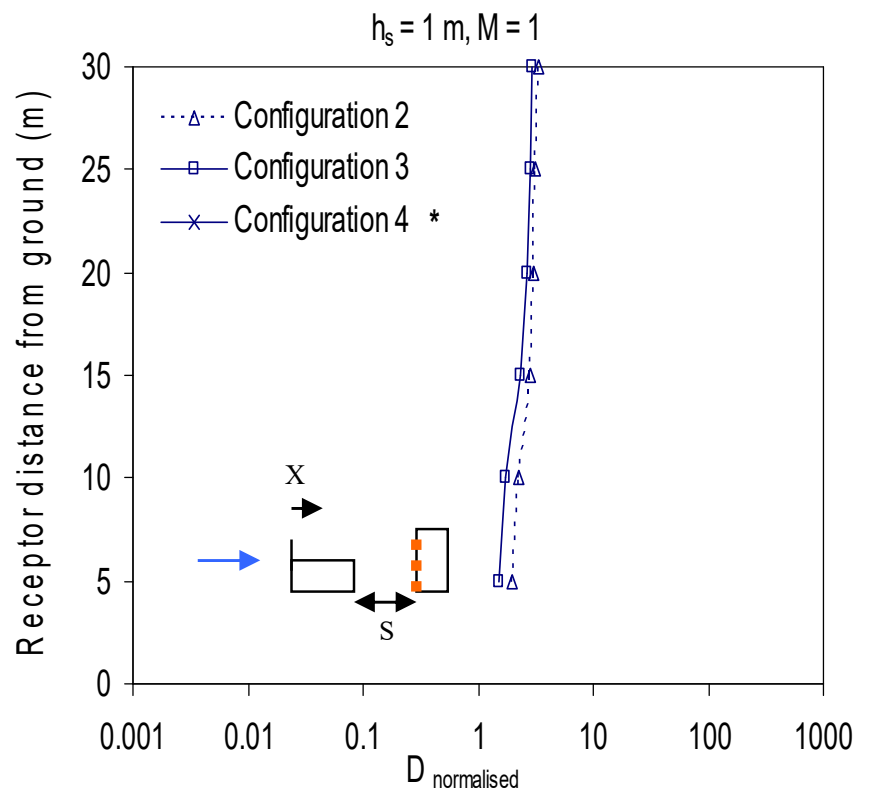

a)

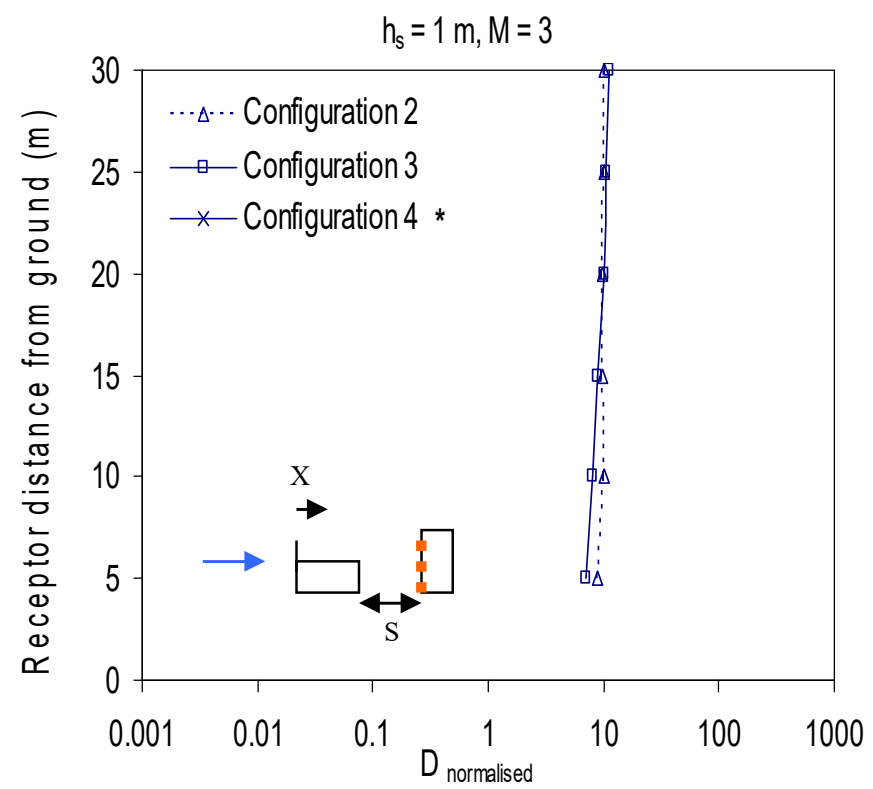

b)

Figure 9. Normalised dilution on windward wall of downstream building for $\mathrm{X}=0$ and $\mathrm{S}$ $=20 \mathrm{~m}$ : a) $\mathrm{M}=1$; b) $\mathrm{M}=3$ (* Concentration of pollutant was measured zero at all receptors)

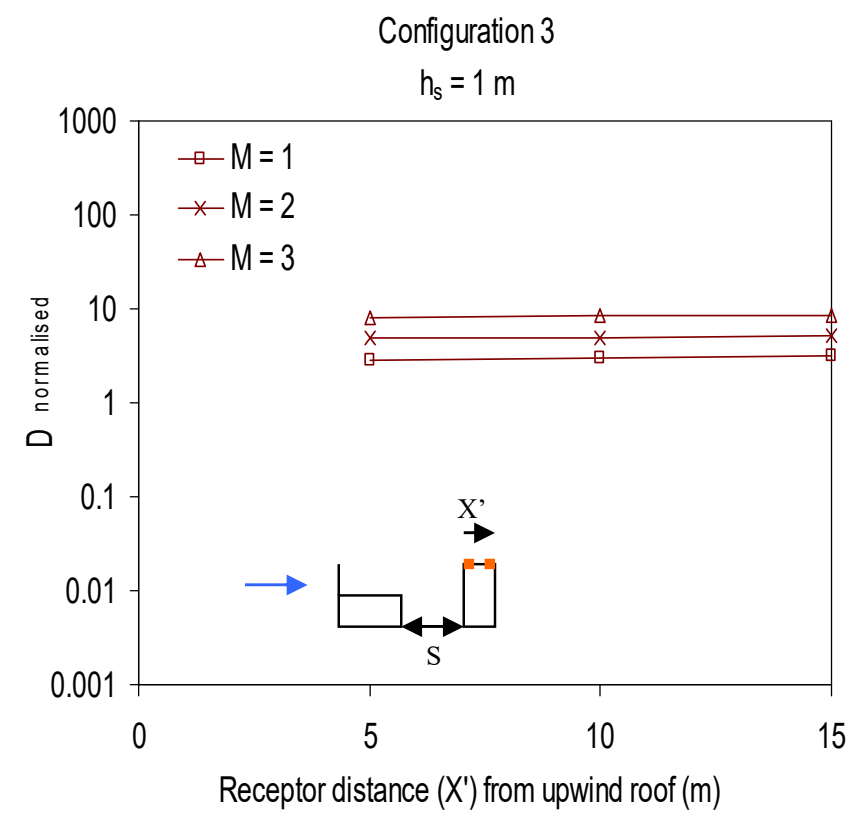

a)

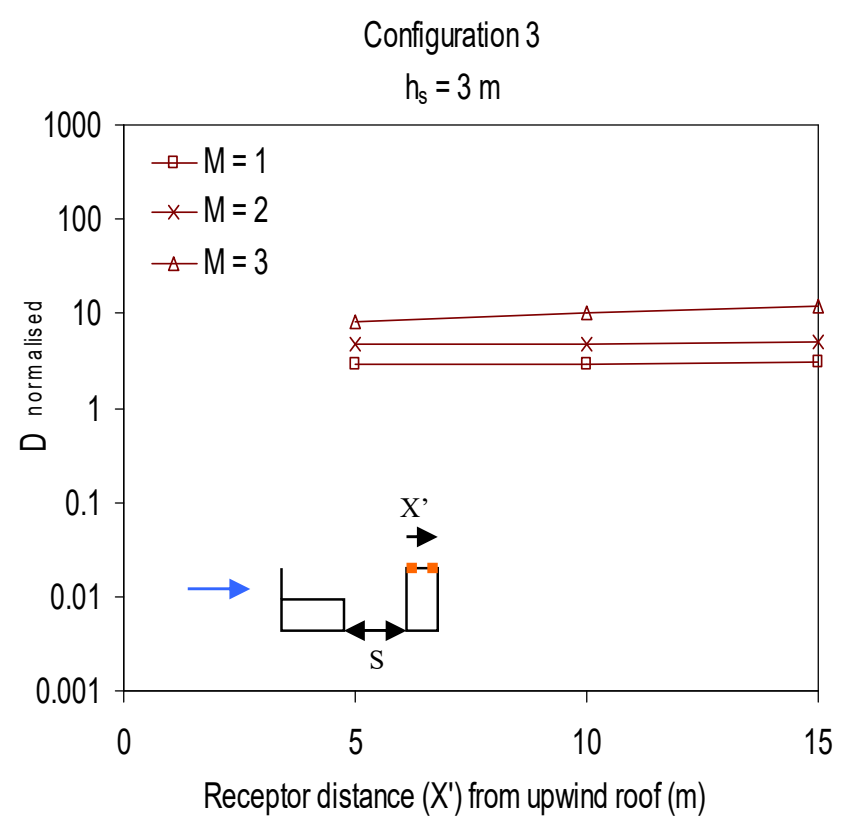

b)

Figure 10. Normalised dilution on rooftop of $B_{3}$ for $S=20 \mathrm{~m}$ : a) $\left.h_{s}=1 \mathrm{~m} ; b\right) h_{s}=3 \mathrm{~m}$ 


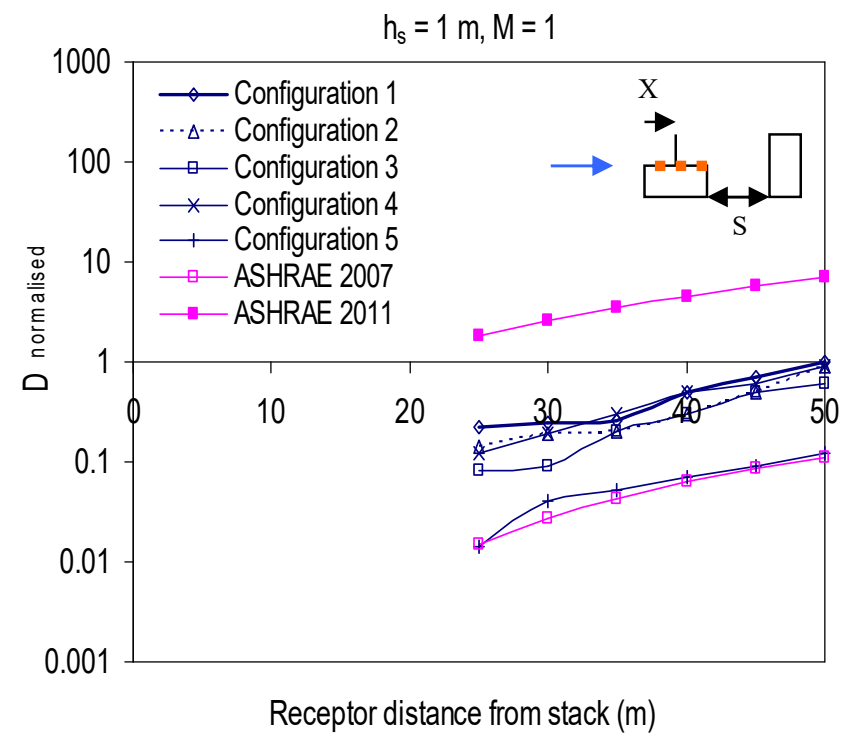

a)

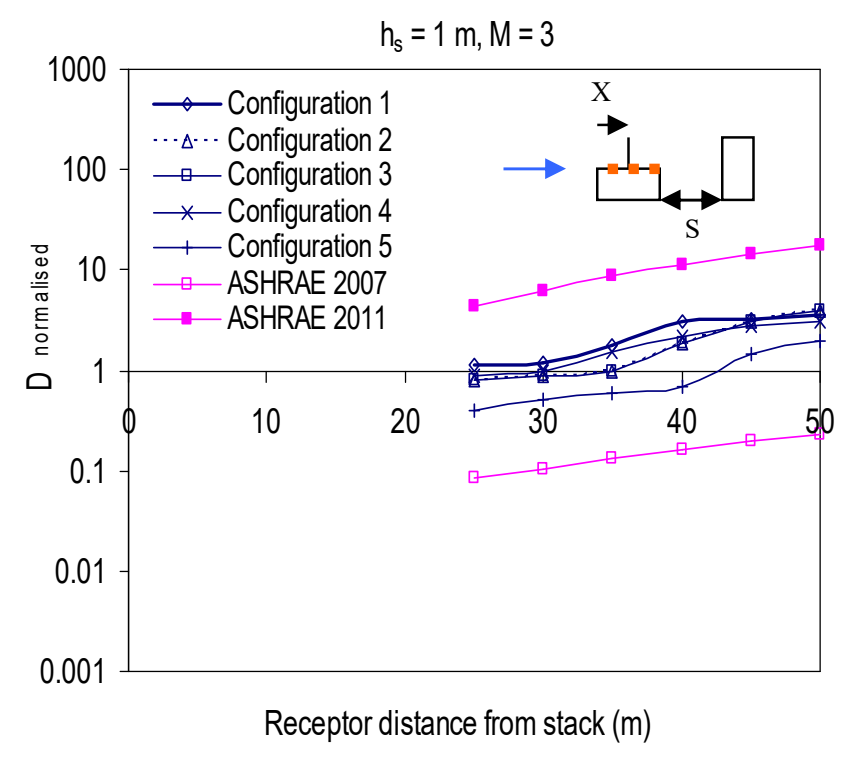

b)

Figure 11. Normalised dilution on rooftop of $B_{1}$ for $X=20 \mathrm{~m}$ and $\left.S=20 \mathrm{~m}: \mathrm{a}\right) \mathrm{M}=1$; b) $\mathrm{M}=3$ (Concentration of pollutant was measured zero at receptors upwind of the stack)

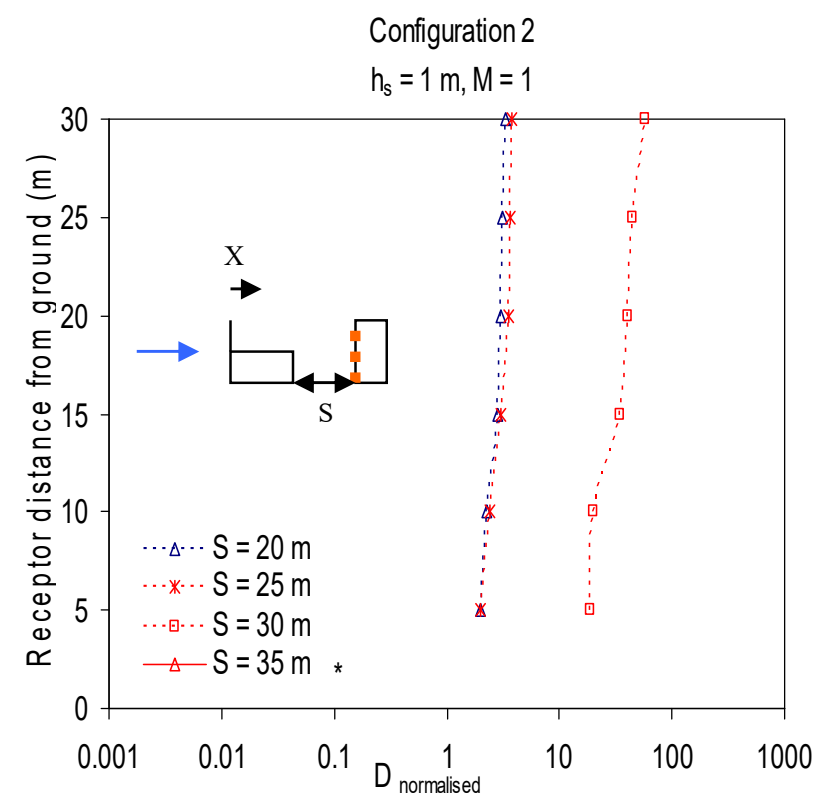

a)

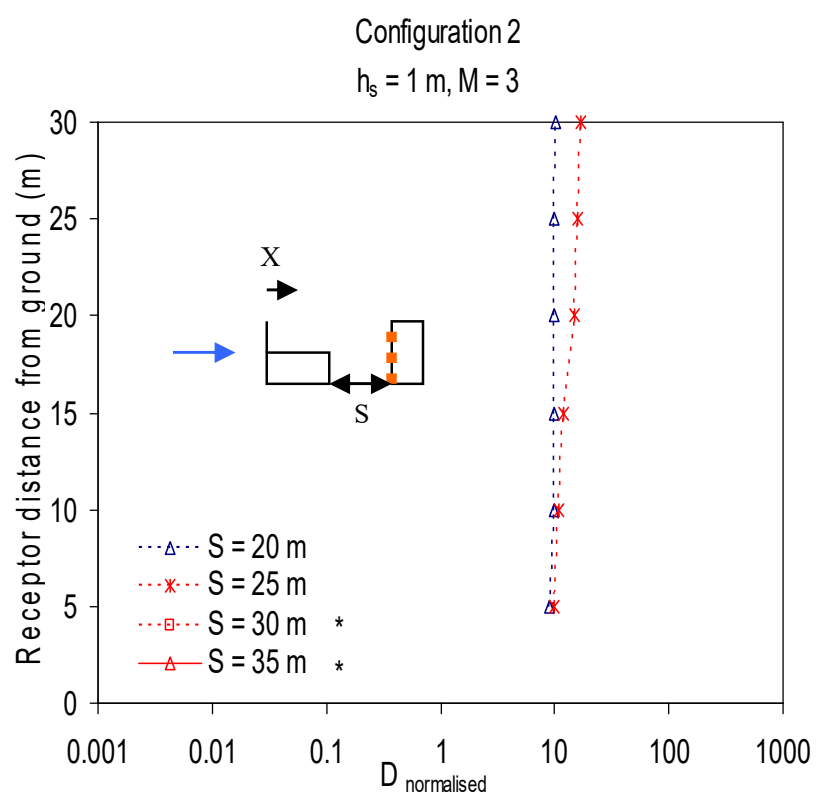

b)

Figure 12. Normalised dilution on windward wall of $\mathrm{B}_{2}$ for different building distances (S) and $\mathrm{X}=0$ : a) $\mathrm{M}=1$; b) $\mathrm{M}=3$ (* Concentration of pollutants was found to be zero) 


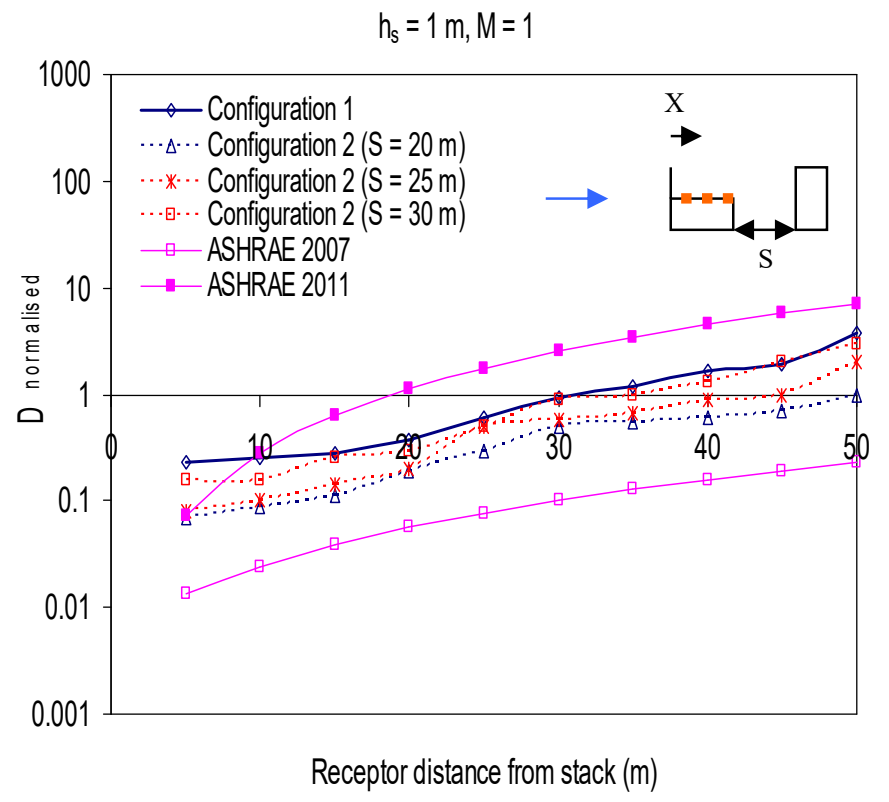

a)

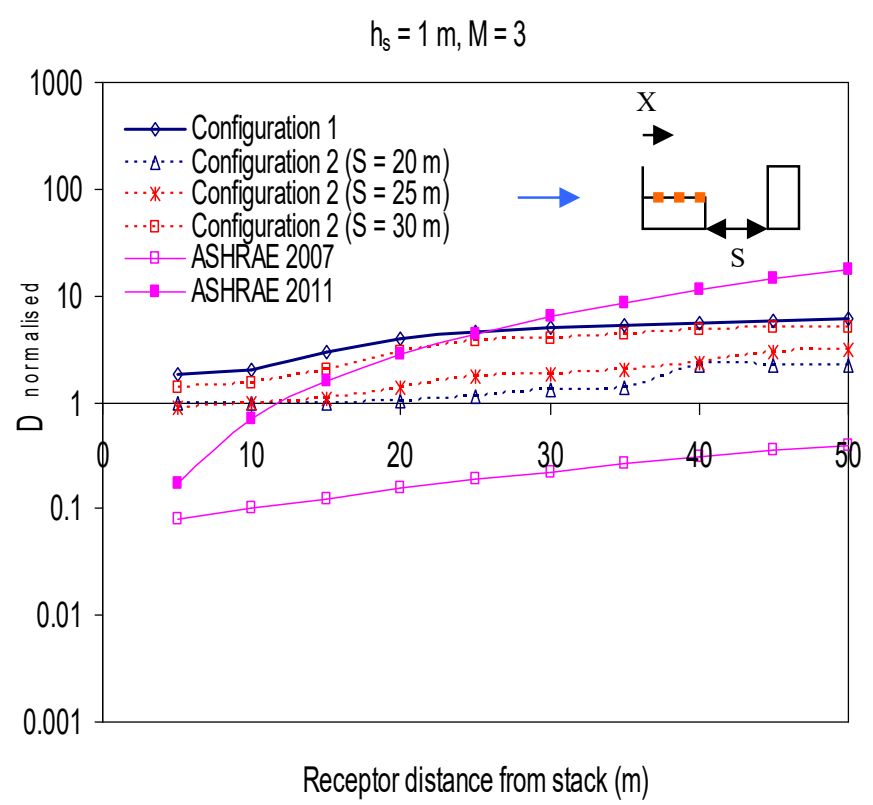

b)

Figure 13. Normalised dilution on rooftop of $\mathrm{B}_{1}$ for different building distances $(\mathrm{S})$ and $\mathrm{X}$ $=0$ : a) $\mathrm{M}=1$; b) $\mathrm{M}=3$ 
Pollutant re-entry

through inlets

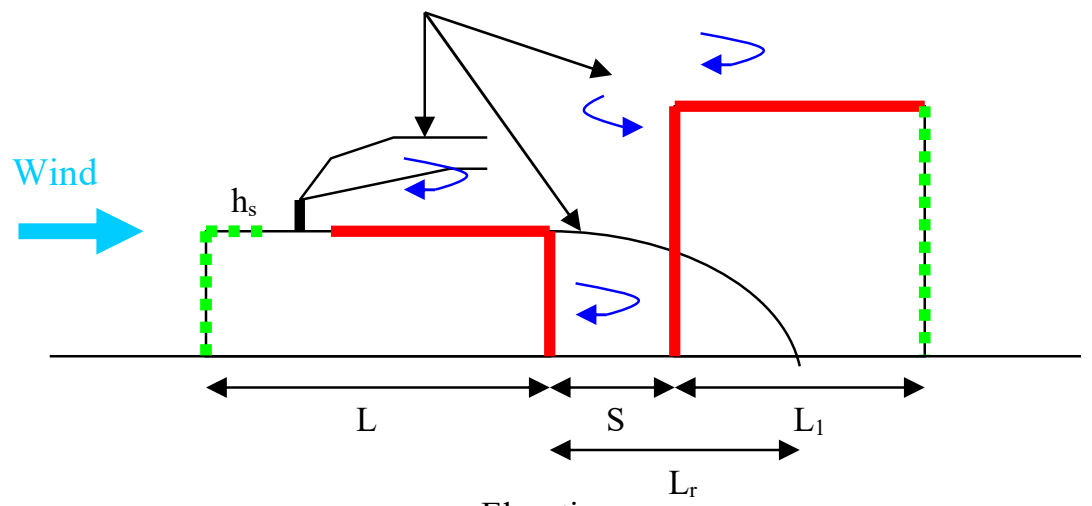

- More suitable for intake location

Unsuitable for intake location

a) $\underline{\mathrm{S}<\mathrm{L}_{\mathrm{r}}}$

Elevation

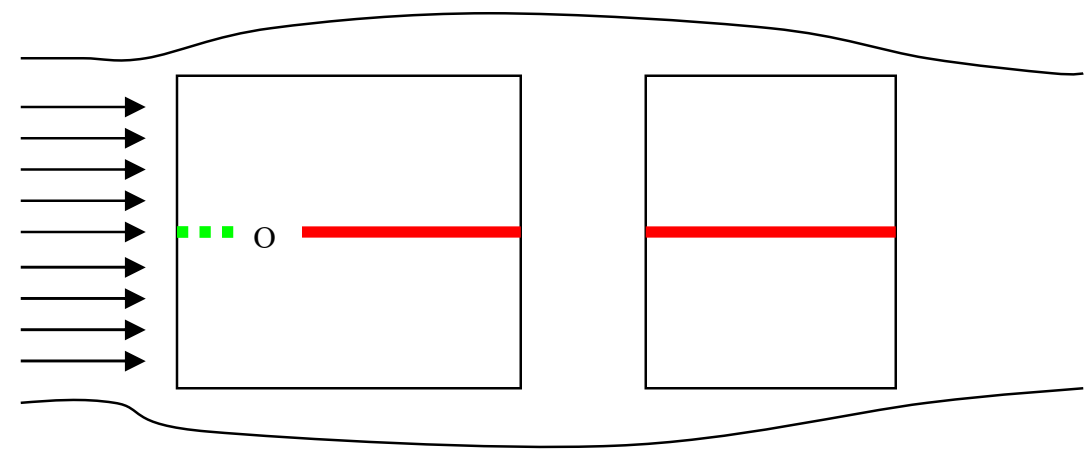

Plan

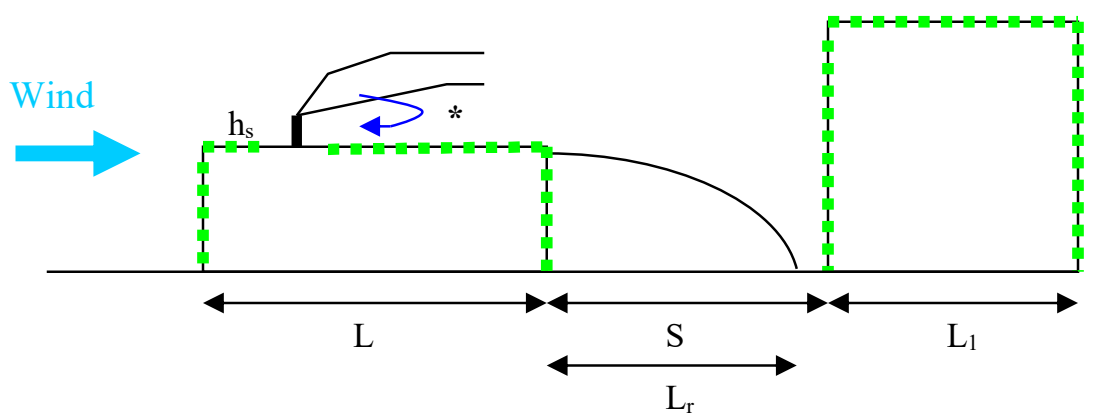

- More suitable for intake location

b) $\underline{\mathrm{S}>\mathrm{L}_{\mathrm{r}}}$

* Pollutants may re-enter at $\mathrm{h}_{\mathrm{s}}=1 \mathrm{~m}$ and $\mathrm{M}=1$ due to increased downwash.

Elevation

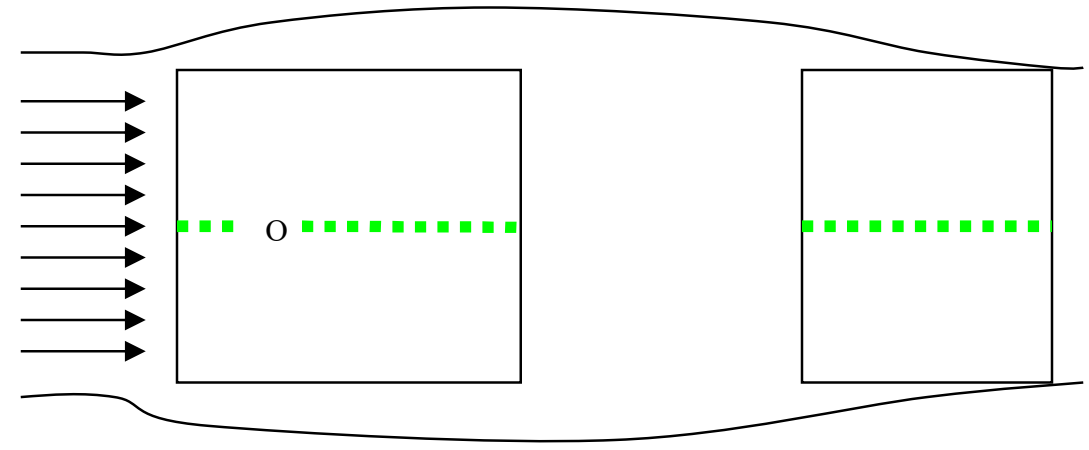

Plan

Figure 14. Schematic representation for suitability of intake location at various building surfaces for: a) $\mathrm{S}<\mathrm{L}_{\mathrm{r}}$; b) $\mathrm{S}>\mathrm{L}_{\mathrm{r}}$ 